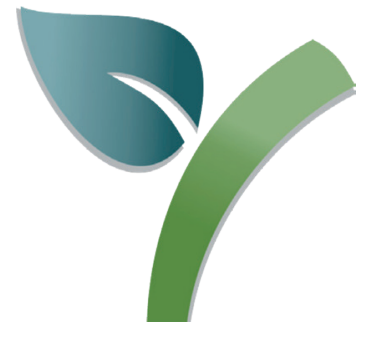

\title{
MANAGEMENT OF BACTERIAL HALO BLIGHT AND OTHER COFFEE CROP DISEASES
}

\author{
Flávia Rodrigues Alves Patricio ${ }^{1,5} \mathbb{C}^{1}$, Luis Otávio Saggion Beriam ${ }^{1} \oplus^{\oplus}$, \\ José Maria Fernandes dos Santos ${ }^{1,6}$, Arivaldo de Moraes ${ }^{2}$, Agnaldo Rossi ${ }^{3}$, \\ Joao Carlos Seixas Reis ${ }^{4}$, Irene Maria Gatti de Almeida ${ }^{1,6}$
}

\section{ABSTRACT}

Bacterial halo blight (BHB), caused by Pseudomonas syringae pv. garcae, has reemerged as an important disease in Brazil, especially in coffee cultivated at high altitude in the states of Minas Gerais and São Paulo. In this study we evaluated copper-based antimicrobial compounds (CBACs), the antibiotic kasugamycin and the resistant inducers acibenzolar-S-methyl (ASM) and phosphite for BHB management in four experiments carried out in coffee crops in the municipalities of Caconde and Altinópolis, São Paulo State, Brazil. Fungicides to control brown leaf spot (BLS), a disease caused by Boeremia exigua pv. coffea, were also included in two experiments, because both diseases frequently occur simultaneously. Copper oxychloride, copper hydroxide, antibiotic, and ASM mixture with copper hydroxide, and phosphite reduced BHB incidence and had no phytotoxic effects on flowers or pin-head berries. Mixtures of boscalid or pyraclostrobin with copper hydroxide were compatible and effective for the simultaneous control of BHB and BLS. In this study, we showed that August-September is the most important period to control BHB in Brazil and lasts until December, when disease incidence increases, and flowers and pin-head berries are being formed. The chemical management of BHB in this period can improve the coffee crop yield.

KEYWORDS: Bacterial halo blight, Pseudomonas syringae pv. garcae, chemical control, copper bactericides, Boeremia exigua pv. coffeae, brown leaf spot.

\section{RESUMO}

A mancha aureolada (MA), causada pela bactéria Pseudomonas syringae pv. garcae, ressurgiu como uma importante doença do cafeeiro, especialmente nas regiões de maiores altitudes dos estados de São Paulo e Minas Gerais. Neste estudo, foram testados compostos antimicrobianos formulados com cobre, o antibiótico casugamicina e dois indutores de resistência, acibenzolar-S-methil (ASM) e fosfito, para o controle da doença em campos infestados nos municípios de Caconde e Altinópolis, SP. Em dois experimentos foram incluídos fungicidas para controlar também a mancha de phoma, causada por Boeremia exigua pv. coffeae, uma vez que essa doença ocorre simultaneamente com a MA. O oxicloreto e o hidróxido de cobre, o antibiótico, o ASM + hidróxido de cobre e o fosfito reduziram a incidência da MA. Misturas do hidróxido de cobre com boscalida e piraclostrobina foram compatíveis e eficientes para o controle simultâneo da MA e da mancha de phoma. Neste estudo, observou-se que a época mais importante para controlar a MA vai de agosto-setembro até dezem-

\footnotetext{
${ }^{1}$ Instituto Biológico, Avenida Conselheiro Rodrigues Alves, 1252, CEP 04014-900, São Paulo, SP, Brazil, ²Cooxupé Alfenas Núcleo 09, Av. Alberto Vieira Romão, 2690, Distrito Industrial, CEP 37.130-000, Alfenas, MG, Brazil, ${ }^{3}$ Casa da Agricultura de São Carlos, Rua

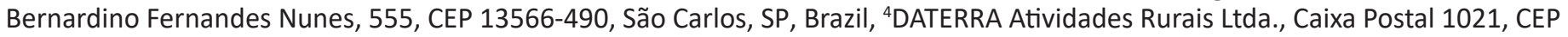
38749-972, Patrocínio, MG, Brazil, ${ }^{5}$ Corresponding author: flavia.patricio@sp.gov.br, ${ }^{6}$ In memorian
} 
bro, período em que as flores e frutos jovens estão se formando, e a incidência da doença aumenta. O manejo da MA nesse período pode proporcionar aumento do rendimento da cultura do café.

PALAVRAS-CHAVE: mancha aureolada, Pseudomonas syringae pv. garcae, compostos antimicrobianos formulados com cobre, Boeremia exigua pv. coffeae, mancha de phoma.

\section{INTRODUCTION}

Bacterial halo blight (BHB), caused by Pseudomonas syringae pv. garcae, affects coffee crops in Brazil (RODRIGUES et al. 2013; PATRICIO \& OLIVEIRA 2013) and other countries, such as Kenya (KAIRU et al. 1985) and Ethiopia (HINKOSA et al. 2016). Bacterial halo blight was first identified in the 1950's in the region of Garça, São Paulo State, Brazil (COSTA et al. 1957) and it has remained a secondary disease for several years in most coffee producing areas in Brazil. However, since 2008, BHB has become more important in coffee cultivated at high altitude in the states of Minas Gerais and São Paulo (ALMEIDA et al. 2012).

Resistant cultivars and windbreakers are recommended for BHB management (PATRICIO \& OLIVEIRA 2013). However, when environmental conditions are very favorable, chemical control is often necessary in susceptible cultivars in most coffee crops in Brazil. Comparing with fungicides, fewer products are available for the control of plant pathogenic bacteria (SUNDIN et al. 2016). Copper based antimicrobial compounds (CBACS) and the antibiotic streptomycin were the initial products applied to control plant pathogenic Pseudomonas spp., Xanthomonas spp. and Erwinia amylovora (SUNDIN et al. 2016). The first studies carried out in Brazil showed that applications of antibiotics formulated with streptomycin were ineffective for controlling BHB (COSTA et al. 1957). Streptomycin-formulated antibiotics were banned from agriculture in Brazil; however, kasugamycin, which is only applied in agriculture, was effective to reduce BHB symptoms in coffee seedlings (PATRICIO et al. 2008). The strategy to pre-induce plants against bacterial plant diseases using resistant inducers, such as acibenzolar-S-methyl (ASM), has been successfully applied in the control of several plant pathogenic bacteria (SUNDIN et al. 2016), in addition, ASM has shown efficacy for BHB control in coffee seedlings (PATRICIO et al. 2008).
Copper based antimicrobial compounds are the most common bactericides to control bacterial plant diseases (CHA \& COOKSEY 1991) and usually have low cost and low toxicity to humans and animals (MARCO \& STALL 1983). These compounds show a broad mode of action against several plant pathogens (LAMICHHANE et al. 2018). However, because they are applied at high rates and in several applications in susceptible crops, populations of Cu-resistant plant pathogenic bacteria were detected in several pathosystems (LAMICHHANE et al. 2018). Moreover, there is an increasing concern about CBACs accumulation in soils causing toxicity to the soil microbiota, as well as residues in fruits and other products (LAMICHHANE et al. 2018). Among the CBACs, cooper oxychloride, copper hydroxide, and cuprous oxide have been used in Brazil to control coffee leaf rust (CLR), caused by Hemileia vastatrix, since the 1970's (MATIELLO \& ALMEIDA 2006). However, the use of these products reduced in coffee crops in Brazil since the introduction of DMI (DeMethylation Inhibitors or triazoles) and Qoi (Quinone outside inhibitors or strubilurins) fungicides (MATIELLO \& ALMEIDA 2006). Copper-based bactericides showed potential for BHB control when the disease was discovered in coffee crops in the region of Garça, in Brazil (COSTA \& SILVA 1960). In Kenya, several applications of CBACs promoted simultaneous control of BHB and coffee berry disease (CBD). In addition, higher yields were obtained in response to the number and doses of the Cu applied (KAIRU et al. 1985; KAIRU et al. 1991). Copper oxychloride also provided BHB control in coffee seedlings (PATRICIO et al. 2008).

To be effective, CBACs need to be well distributed in the plant canopy and have some tenacity to rain lixiviation; thus, the use of adjuvants may improve their distribution and permanence in the crop. Adjuvants are added to pesticide solutions to change drop size, viscosity, and surface tension and thus improve their distribution on the leaves and 
other parts of the plant canopy (BAIO et al. 2015). Among the commercially available adjuvants, mineral and vegetable oils, as well as silicone adhesive, can have different effects when mixed with spray solutions (BAlO et al. 2015).

Brown leaf spot (BLS) is another frequent disease in coffee grown at high altitude and is caused by Boeremia exigua pv. coffeae (AVESKAMP et al. 2010), previously known as Aschochyta tarda, and reclassified as Phoma tarda by BOEREMA et al. (2004). BLS causes lesions in young leaves, dieback of young branches, flowers, and pin-head berries (PATRICIO \& OLIVEIRA 2013). Cold winds and rains are environmental conditions favorable to this disease, which is frequently associated to BHB (PATRICIO \& OLIVEIRA 2013), and both diseases frequently occur and are controlled simultaneously in coffee crops.

Most coffee crops in Brazil are susceptible to $\mathrm{BHB}$. Therefore, we evaluated BHB management under field conditions in the municipalities of Caconde and Altinopolis, State of São Paulo, Brazil. We tested CBACs mixed with different additives as well as the antibiotic kasugamycin and resistant inducers Acibenzolar-S-Methyl (ASM) and phosphite. Two experiments were also designed to simultaneously control BHB and BLS, as both diseases often occur in the same area.

\section{REVIEW}

In December 1955, researchers from Instituto Agronômico, Campinas, São Paulo State, found a new disease in coffee crops in the municipality of Garça, State of São Paulo (COSTA et al. 1957). At that time, Garça was the main coffee producer in Brazil (IBGE 2016). The symptoms appeared in young coffee plants, especially in areas subjected to strong winds. The leaves showed brown lesions surrounded by a yellow halo and the plants were severely defoliated (COSTA et al. 1957). A bacterium was isolated from those leaf lesions, and, after inoculations, similar symptoms were observed in the leaves. Biochemical tests were carried out at Instituto Biológico, São Paulo State, and the bacteria was identified as Pseudomonas syringae, but it was named as Pseudomonas garcae (COSTA et al. 1957). Later, it was renamed as $P$. syringae pv. garcae after the pathovar nomenclature was adopted (RAMOS 1976). In Kenya, although "Elgon die back" was detected in the 1930s and originally attributed to Colletotrichum coffeanum (FIRMAN 1963), and RAMOS \& SHADVIA (1976) showed that the disease was caused by $P$. syringae pv. garcae. The disease occurs in Brazil (ALMEIDA et al. 2012), Kenya, India, China (KAIRU et al. 1985) and was recently related and studied in Ethiopia (HINKOSA et al. 2016).

Bacterial halo blight remained unnoticed in Brazil for several years. However, after the great frost plagued Paraná State in 1975, most coffee plants that sprouted after frost were severely affected by the disease and BHB became endemic in that state in the subsequent years (MOHAN et al. 1978). In the 1980's, BHB was reported in the Cerrado region of Minas Gerais State (ZOCCOLI et al. 2011). The disease remained endemic to crops at altitudes of $950 \mathrm{~m}$ or above in the Cerrado region (ZOCCOLI et al. 2011). Since 2008, coffee samples of branches and leaves showing BHB symptoms arrived at Instituto Biológico from proprieties in the Brazilian States of Minas Gerais and São Paulo (ALMEIDA et al. 2012). At Instituto Biológico, $80 \%$ of the $P$. syringae pv. garcae isolates obtained since 2008 were from coffee crops situated at altitudes higher than $800 \mathrm{~m}$ above sea level (MACIEL et al. 2018). Bacterial halo blight became severe also in nurseries in many coffee producing areas of Minas Gerais and São Paulo (ZOCCOLI et al. 2011, ALMEIDA et al. 2012).

The increase in BHB incidence in coffee far$\mathrm{ms}$ in Brazil may be related to migration of the coffee crops from regions of lower altitudes to higher altitudes in the states of Minas Gerais and São Paulo (IBGE 2016). Currently, the regions that produce most Arabica coffee in Brazil comprise many fields at $800 \mathrm{~m}$ above sea level in southern Minas Gerais State and its western savanna-like Cerrado, as well as in the Mogiana region in São Paulo State (IBGE 2016). High altitudes are very favorable for the coffee crops and less susceptible to frosts; nevertheless, the incidence of strong winds during the whole year can be favorable to BHB incidence and spread (ALMEIDA et al. 2012, PATRICIO \& OLIVEIRA 2013). In addition, pruning became an integral part of the coffee crop management and causes lesions to the plant tissues favoring penetration of the bacteria (PATRICIO \& OLIVEIRA 2013). Bacterial halo blight was possibly introduced from infected seedlings, confirmed in a study of several P. syringae pv. garcae isolates, in which by molecular approaches (ERIC- and RT-PCR) it was observed that they could be grouped by their 
geographic origin and year of isolation (MACIEL et al. 2018).

Bacterial halo blight symptoms comprise lesions in the leaves, flowers, and pin-head berries, as well as dieback of twigs and branches (COSTA et al 1957, ALMEIDA et al. 2012; PATRICIO \& OLIVEIRA 2013). The disease is more prevalent in young plants up to four years old. The bacteria penetrate the plant tissues mainly through breakages caused by strong winds or various types of pruning (MOHAN et al. 1978, PATRICIO \& OLIVEIRA 2013) as well as natural openings in the leaf and flower tissues (ALMEIDA et al. 2012, PATRICIO \& OLIVEIRA 2013).

Resistance to BHB was not considered in most coffee breeding programs in Brazil, probably because BHB remained unnoticed for several years. The main sources of resistance seems to come from genotypes from Ethiopia, as well as $C$. canephora and $C$. canephora $\times$ C. arabica hybrids, and other Coffea species. MOHAN et al. (1978) showed that $36 \%$ of genotypes from Ethiopian origin from IAPAR collection were resistant to $\mathrm{BHB}$. The $\mathrm{SH}_{1}$ resistance gene confers resistance to coffee cultivars against some races of CLR and was believed to have a pleiotropic effect also providing resistance to BHB. Coffee plants containing the $\mathrm{SH}_{1}$ factor, from cultivars Harar, Geisha, Dilla and Alghe, S12-K, and others, especially from Ethiopian origin, were less affected by Elgon die back in Kenya (FIRMAN 1963), and resistant to BHB in experiments carried out in Brazil (MORAES et al. 1975, MOHAN et al. 1978, PETEK et al. 2005). However recent studies showed that the $\mathrm{SH}_{1}$ gene has no genetic linkage to CLR and BHB resistance (RODRIGUES et al. 2017) and coffee cultivars Dilla and Geisha showed susceptibility to some P. syringae pv. garcae strains in Kenya (ITHIRU et al. 2016).

An important source of resistance comes from $C$. canephora and crosses with hybrids of $C$. arabica and C. canephora. In Paraná State (Brazil), where the disease became endemic after the "1970 Big Frost", MOHAN et al. (1978) observed that most coffee cultivars and introductions of new genotypes where susceptible to BHB; however, the authors found less disease incidence in some Icatu cultivars (crosses between C. arabica cultivar Bourbon and C. canephora). Bacterial halo blight was subsequently evaluated in the coffee breeding programs of Paraná State, especially because the studies continued to be carried out in infested crops. The breeding program at Instituto Agronômico (IAC) (Brazil) sent some Icatu cultivars to IAPAR, which were crossed with the cultivar Catuai resulting in cultivars IPR 102, resistant to BHB (PETEK et al. 2005, ITO et al. 2008, SERA et al. 2017), and IPR 103, moderately resistant do BHB (PETEK et al. 2005, ITO et al. 2008). Other cultivars derived from the Timor Hybrid (natural cross between $C$. arabica $\times C$. canephora) showed resistance to BHB, such as Ruiru II, Rume Sudan, and Bastian in Kenya, and some genotypes in Brazil (ITHIRU et al. 2013, ITHIRU et al. 2016, ANDREA$\mathrm{Zl}$ et al. 2018). Other species of the genus Coffea may also be sources of BHB resistance, such as $C$. eugenioides, which is a resistance source to leaf miner (Leucoptera coffeela) (MOHAN et al. 1978, ANDREAZI et al. 2018; RODRIGUES et al. 2019); as well as Coffea stenophila, C. liberica, C. canephora, C. congencis and C. salvatrix (MOHAN et al. 1978, RODRIGUES et al. 2019).

The use of resistant genotypes is the most economic and efficient method to control any plant disease. However, currently, only commercial cultivar IPR 102 is considered highly resistant to BHB (SERA et al. 2017), requiring other control methods in infested coffee crops. Because constant winds play an important role in BHB severity, the use of healthy seedlings and planting windbreakers are important strategies to manage BHB (PATRICIO \& OLIVEIRA 2013). Annual crops, such as pigeon pea, crotalaria, corn, and others, can be used to protect the coffee crop during the initial growth of the transplanted seedlings, while trees, such as avocado, banana, eucalyptus, and others, can be used as permanent windbreakers (PATRICIO \& OLIVEIRA 2013). When environmental conditions are favorable to $\mathrm{BHB}$, chemical control with CBACs is also recommended (PATRICIO \& OLIVEIRA 2013), however, their use was seldom studied in Brazil. Because BHB is still a limiting factor to coffee cultivated at high altitude and a challenge to coffee growers and seedling producers, breeding programs should include this disease and studies on chemical control in field conditions shouId be continued.

\section{MATERIAL AND METHODS}

In this work, four experiments were carried out in field conditions to evaluate the chemical control of BHB and other coffee diseases.

The products used in this study were kasugamycin (20 g a.i./L), copper hydroxide $(691 \mathrm{~g} / \mathrm{kg}$ ), 
copper oxychloride (870 g a.i./kg), and acibenzolar-S-methyl (500 g a.i./ $\mathrm{kg}$ ). We investigated if additives increased or caused phytotoxicity in coffee plants, therefore, we evaluated a mineral oil (726 g a.i./L), a vegetable oil (720 a.i./L), and silicone adhesive (100\% polyether-polymethyl siloxane copolymer). In Altinópolis, two fungicides, boscalid (500 g a.i./ $\mathrm{kg}$ ) and pyraclostrobin (500 g a.i./ $\mathrm{kg}$ ), were included to evaluate the simultaneous control of $\mathrm{BHB}$, brown eye spot (BES) (caused by Cercospora coffeicola), and BLS (caused by Boeremia exigua pv. coffeae). The treatment with copper phosphite was included because the coffee farmer from the experimental area in Altinópolis used it in the 2010-2011 season. The product formulated with thiamethoxan (300 g a.i./ $\mathrm{kg}$ ) + cyproconazole (300 g a.i./ $\mathrm{kg}$ ) was applied to control CLR, caused by Hemilia vastatrix, and coffee leaf miner, Leucoptera coffeella.

Experiments in Caconde (São Paulo State) The first and second experiments were carried out in the municipality of Caconde, São Paulo State, in two coffee (cultivar Novo Mundo) plantations areas, $21^{\circ} 54^{\prime}$ lat and $46^{\circ} 71^{\prime}$ long, at 100 to $1,100 \mathrm{~m}$ above sea level, with spacing $3.0 \mathrm{~m} \times 2.0 \mathrm{~m}$, two plants per pit. The municipality of Caconde has a Cwa climate with hot and humid summers and dry and cold-to-mild winters, and 1,479 $\mathrm{mm}$ of annual average precipitation. The plants were pruned five years earlier and BHB was present in both sites, possibly due to two previous rainy winters and the inci- dence of winds. In both experiments, the chemicals were applied in 2009 (September 30, November 4, December 10) and in 2010 (March 19), which was performed when the disease incidence began to increase again. The products were applied in a volume equivalent to $400 \mathrm{~L}$ of suspension per hectare (ha) with a backpack handheld sprayer from the brand Jacto model PJH with a D2 hollow cone nozzle, a common device used in small coffee farms in Brazil. The chemicals and their active ingredients applied by hectare are described in Tables 1 and 2 for the first and second experiments, respectively. In the first experiment, the treatments were designed to control BHB. In the second experiment, fungicides such as pyraclostrobin and boscalid were included to evaluate simultaneous control of $\mathrm{BHB}$ and other coffee diseases, such as BES and BLS.

In December 2009, the product formulated with thiamethoxan and cyproconazole was applied in the soil under the plant canopy of the coffee plants with a handheld backpack sprayer at the rate of $1 \mathrm{~kg} / \mathrm{ha}$ to provide protection against CLR and coffee leaf miner.

Experiments in Altinópolis (São Paulo State) - We carried out one experiment in the municipality of Altinópolis, São Paulo State, Brazil, in 2009/2010 and another in 2010/2011. The experiments were conducted in a four-year-old coffee (cultivar Novo Mundo) plantation and spaced at $3.5 \mathrm{~m} \times 0.8 \mathrm{~m}$ $\left(21^{\circ} 01^{\prime}\right.$ lat and $47^{\circ} 37^{\prime}$ long and $960 \mathrm{~m}$ above sea lev-

Table 1. Chemicals applied to a coffee (cultivar Mundo Novo) plantation for the control of bacterial halo blight (BHB), caused by Pseudomonas syringae pv. garcae, in the municipality of Caconde, São Paulo State, Brazil, in the first experiment carried out in 2009-2010.

\begin{tabular}{lcr}
\hline Treatments & Commercial product doses /ha & Active ingredient doses /ha \\
\hline 1. Control & \multicolumn{1}{c}{$1.5 \mathrm{~L}$} & - \\
\hline 2. Kasugamycin & $1.5 \mathrm{~L}+2.5 \mathrm{~kg}+0.1 \mathrm{~L}$ & $0.030 \mathrm{~kg}+1.74 \mathrm{~kg}+0.1 \mathrm{~L}$ \\
\hline 3. Kasugamycin + Copper hydroxide + Silicone Adhesive & $2.5 \mathrm{~kg}+1.0 \mathrm{~L}$ & $1.74 \mathrm{~kg}+0.72 \mathrm{~kg}$ \\
\hline 4. Copper hydroxide + Vegetal oil & $2.5 \mathrm{~kg}+1.0 \mathrm{~L}$ & $1.74 \mathrm{~kg}+0.756 \mathrm{~kg}$ \\
\hline 5. Copper hydroxide + Mineral oil & $2.5 \mathrm{~kg}+0.1 \mathrm{~L}$ & $1.74 \mathrm{~kg}+0.1 \mathrm{~L}$ \\
\hline 6. Copper hydroxide + Silicone Adhesive & $2.5 \mathrm{~kg}+0.050 \mathrm{~kg}+0.1 \mathrm{~L}$ & $1.74 \mathrm{~kg}+0.025 \mathrm{~kg}+0.1 \mathrm{~L}$ \\
\hline 7. Copper hydroxide + Acibenzolar-S-methyl + Silicone Adhesive & $4.0 \mathrm{~kg}$ & $3.48 \mathrm{~kg}$ \\
\hline 8. Copper oxychloride & $0.050 \mathrm{~kg}$ & $0.025 \mathrm{~kg}$
\end{tabular}

${ }^{1}$ The treatments were applied on September 30, 2009, November 4, 2009, December 10, 2009, March 19, 2010. 
Table 2. Chemicals applied to a coffee (cultivar Mundo Novo) plantation for the control of bacterial halo blight (BHB), caused by Pseudomonas syringae pv. garcae and other coffee diseases in the municipality of Caconde, São Paulo State, Brazil, in the second experiment carried out in 2009/2010.

\begin{tabular}{lcc}
\hline Treatments & Commercial product doses /ha & Active ingredient doses /ha \\
\hline 1. Control & $2.5 \mathrm{~kg}+0.1 \mathrm{~L}$ & - \\
\hline 2. Copper hydroxide + Silicone Adhesive & $2.5 \mathrm{~kg}+0.4 \mathrm{~L}+0.1 \mathrm{~L}$ & $1.74 \mathrm{~kg}+0.1 \mathrm{~L}$ \\
\hline 3. Copper hydroxide + Pyraclostrobin + Silicone Adhesive & $2.5 \mathrm{~kg}+0.15 \mathrm{~L}+0.1 \mathrm{~L}$ & $1.74 \mathrm{~kg}+0.075 \mathrm{~kg}+0.1 \mathrm{~L}$ \\
\hline 4. Copper hydroxide + Boscalid + Silicone Adhesive & $0.4 \mathrm{~L}$ & $0.2 \mathrm{~kg}$ \\
\hline 5. Pyraclostrobin & $0.15 \mathrm{~kg}$ & $0.075 \mathrm{~kg}$ \\
\hline 6. Boscalid & $0.4 \mathrm{~L}+0.15 \mathrm{~kg}$ & $0.2 \mathrm{~kg}+0.075 \mathrm{~kg}$
\end{tabular}

${ }^{1}$ The treatments were applied on September 30, 2009, November 4, 2009, December 10, 2009, March 19, 2010.

el). The municipality of Altinópolis has a Cwa climate and 1,338 $\mathrm{mm}$ of average annual precipitation.

The products were sprayed with a turbo Jacto ARBUS 400, a device commonly used in coffee crops in large and mechanized properties. A volume equivalent to $400 \mathrm{~L}$ of solution per ha was applied at $4 \mathrm{~km}$ per hour and $100 \mathrm{psi}$. In the first season (2009/2010), each experimental plot contained four rows with 20 plants each. In the second season (2010/2011), each experimental plot comprised four rows with 60 plants each. The opposing spray nozzles were closed for application on the outer rows on both sides of the plot, but all nozzles were opened in the two central rows. In the 2009/2010 experiment, the products were applied on November 20, 2009;
December 23, 2009; February 12, 2010 (Table 3). In the 2010/2011 season, the chemicals were applied on November 17, 2010; December 14, 2010; January 23, 2011; and May 28, 2011, when the disease incidence began to increase (Table 4).

Evaluation of the experiments - In the experiments carried out in Caconde in 2009-2010, $\mathrm{BHB}$ incidence was evaluated in the eight central plants of each plot on November 5, 2009; January 15, 2009; and April 20, 2010. In the last evaluation in April, 80 leaves were collected on both sides of the plants in the medium-third of the plant canopy in each plot. The leaves were examined for BHB presence and other diseases, such as CLR, BES, and BLS. On June 17, 2010, the production of each plot was

Table 3. Chemicals applied in a coffee (cultivar Mundo Novo) plantation for the control of bacterial halo blight (BHB), caused by Pseudomonas syringae pv. garcae, and other diseases, in the municipality of Altinópolis, São Paulo State, Brazil, in the third experiment carried out in 2009-2010.

\begin{tabular}{lcc}
\hline Treatments & Commercial product doses /ha & Active ingredient doses /ha \\
\hline 1. Control & $2.5 \mathrm{~kg}+0.1 \mathrm{~L}$ & - \\
\hline 2. Copper hydroxide + Silicone Adhesive & $2.5 \mathrm{~kg}+1.0 \mathrm{~L}$ & $1.74 \mathrm{~kg}+0.1 \mathrm{~L}$ \\
\hline 3. Copper hydroxide + Mineral oil & $1.5 \mathrm{~L}+2.5 \mathrm{~kg}+0.1 \mathrm{~L}$ & $0.030 \mathrm{~kg}+1.74 \mathrm{~kg}+0.1 \mathrm{~L}$ \\
\hline 4. Kasugamycin + Copper hydroxide + Silicone Adhesive & $2.5 \mathrm{~kg}+0.4 \mathrm{~L}+0.1 \mathrm{~L}$ & $1.74 \mathrm{~kg}+0.2 \mathrm{~kg}+0.1 \mathrm{~L}$ \\
\hline 5. Copper hydroxide + Pyraclostrobin + Mineral oil & $2.5 \mathrm{~kg}+0.15 \mathrm{~L}+0.1 \mathrm{~L}$ & $1.74 \mathrm{~kg}+0.075 \mathrm{~kg}+0.1 \mathrm{~L}$ \\
\hline 6. Copper hydroxide + Boscalid + Mineral oil & $2.0 \mathrm{~kg}$ & $1.1+0.1$ \\
\hline 8. Metiram + Pyraclostrobin & $2.5 \mathrm{~kg}+2.0 \mathrm{~kg}+0.25 \%$ & $1.7+1.1+0.1$ \\
\hline 9. Copper hydroxide + Metiram + Pyraclostrobin + Mineral oil & $2.5 \mathrm{~kg}+1.0 \mathrm{~L}+0.025 \%$ & $1.1+0.1$
\end{tabular}

${ }^{1}$ The treatments were applied on November 20, 2009; December 23, 2009; February 12, 2010. 
Table 4. Chemicals applied in a coffee (cultivar Mundo Novo) plantation for the control of bacterial halo blight (BHB), caused by Pseudomonas syringae pv. garcae, and other diseases, in the municipality of Altinópolis, São Paulo State, Brazil, in the fourth experiment carried out in 2010-2011.

\begin{tabular}{|c|c|c|}
\hline Treatments $^{1}$ & Commercial product doses /ha & Active ingredient doses /ha \\
\hline 1. Control & - & - \\
\hline 2. Copper hydroxide + Silicone adhesive & $2.5 \mathrm{~kg}+0.1 \mathrm{~L}$ & $1.74 \mathrm{~kg}+0.1 \mathrm{~L}$ \\
\hline 3. Copper hydroxide + Pyraclostrobin + Silicone adhesive & $2.5 \mathrm{~kg}+0.4 \mathrm{~L}+0.1 \mathrm{~L}$ & $1.74 \mathrm{~kg}+0.2 \mathrm{~kg}+0.1 \mathrm{~L}$ \\
\hline 4. Copper hydroxide + Boscalid + Silicone adhesive & $2.5 \mathrm{~kg}+0.15 \mathrm{~kg}+0.1 \mathrm{~L}$ & $1.74 \mathrm{~kg}+0.075 \mathrm{~kg}+0.1 \mathrm{~L}$ \\
\hline $\begin{array}{l}\text { 5. Copper hydroxide + Pyraclostrobin + Boscalid + Silicone ad- } \\
\text { hesive }\end{array}$ & $2.5 \mathrm{~kg}+0.4 \mathrm{~L}+0.15 \mathrm{~kg}+0.1 \mathrm{~L}$ & $1.74 \mathrm{~kg}+0.2 \mathrm{~kg}+0,075 \mathrm{~kg}+0.1 \mathrm{~L}$ \\
\hline 6. Copper phosphite & $2,5 \mathrm{~L}$ & $0.5 \mathrm{~L}$ \\
\hline
\end{tabular}

${ }^{1}$ The treatments were applied on November 17, 2010; December 14, 2010; January 23, 2011; and May $28,2011$.

estimated by the manual harvest of five plants per plot. In addition, 80 leaves were collected from the medium-third of the coffee plant canopy and evaluated for the incidence of the same diseases.

Bacterial halo blight incidence was evaluated in 10 branches from the upper part of the plant canopy, five on each side of the plant. The branches were examined and counted as infected when they exhibited BHB symptoms in the first or second pairs of leaves, or recent dieback.

In the first and second experiments carried out in Altinópolis, we evaluated 20 plants per plot from the two central rows of each experimental plot, 10 plants per line. In the 2009/2010 season, the evaluations were performed on December 22, 2009; January 13, 2010; and April 23, 2010. We used the same methodology applied in the Caconde to evaluate $\mathrm{BHB}$ incidence. In the evaluation carried out in April, 80 leaves were collected on both sides of the plants in the medium third of the plant canopy in each plot and the leaves were examined for BHB presence and other diseases, such as CLR, BES, and BLS. In the 2010/2011 season, the evaluations were performed on December 14, 2010; January 23, 2011; March 27, 2011; May 28, 2011; September 3, 2011, and December 7, 2011. The methodology was the same applied in the Caconde experiment. Other diseases, such as BES, BLS, and dieback of branches caused by $B$. exigua pv. coffeae, were assessed in the first or second pairs of the leaves of the same branches on May 28, 2011. We collected 100 leaves on both sides of the plants in the medium third of the plant canopy in each plot and the leaves were examined for BHB presence and the other diseas- es. Trapezoidal integration was used to calculate the area under the disease progress curve (AUDPC) for the 2011-2012 experiment.

Weather data - the meteorological parameters maximum (Tmax) and minimum (Tmin) temperatures and precipitation (Ppt) were obtained from the Campbell automatic station of Cooxupé, in Guaxupé (760 m altitude) in Minas Gerais State, $38.8 \mathrm{~km}$ from the experimental site of Caconde and very similar in climatic conditions. The meteorological parameters for Altinópolis were obtained from the Instituto Agronômico (IAC) from a Campbell station in the municipality of Franca (1,040 m altitude), $79 \mathrm{~km}$ from Altinópolis (940 m altitude), because there was not a meteorological station in Altinópolis at the time of the experiment.

Statistical analysis - all experiments were carried out in a randomized block design with four repetitions. Data on disease incidence, as well as the production of the experiments in Caconde and Altinóppolis, was subjected to ANOVA. The means were compared by the Scott-Knott test at $5 \%$ probability. BHB incidence and yield were subjected to the regression analysis to evaluate $\mathrm{BHB}$ incidence correlation to plot yield.

\section{RESULTS}

In the first experiment carried out in Caconde, the treatments with kasugamycin + silicone adhesive (SA), copper hydroxide + kasugamycin + SA, copper hydroxide + vegetable oil or mineral oil or SA or ASM reduced $\mathrm{BHB}$ incidence in the second evaluation (Table 5). In this first experiment, the block effect was significant. However, there was no interaction be- 
tween blocks and treatments. BHB affected more intensively plots in the first block of the experimental site than plots in the lower parts, with significant statistical difference. This is possibly attributed to the higher incidence of winds in these parts of the experimental site. Although BHB incidence in the leaves collected in May 2010 was lower in the treated plots, the difference was not statistically significant. Coffee leaf rust incidence reduced in all treated plots, but there was no effect of the treatments on BHB and BES (data not shown). As observed for BHB incidence, there was a block effect for coffee crop yield. Plots at higher altitudes showed lower yield than plots in the blocks at lower altitudes of the experimental site. The treatments with copper hydroxide + silicone adhesive, copper hydroxide + ASM, and copper oxychloride resulted in higher coffee yields per plot (Table 5). The correlation between BHB incidence and yield in the evaluations on November 5, 2009, and January 15,2010 was -0.49945 and -0.47703 , and significant at $0.05 \%$ of probability.

In the second experiment carried out in $\mathrm{Ca}$ conde, the treatments with copper hydroxide + silicone adhesive, copper hydroxide + pyraclostrobin + silicone adhesive, and pyraclostrobin showed lower disease incidence in the second evaluation in all treatments, except for boscalid, which reduced $\mathrm{BHB}$ incidence in the third evaluation. All treatments reduced $B H B$ and $C L R$ incidence in the leaves. All treatments were more effective for CLR control than the treatment with boscalid only; nevertheless, only the treatments with boscalid reduced BLS incidence, caused by $B$. exigua pv. coffeae in the leaves (Table 6). Treatments with copper hydroxide + boscalid or pyraclostrobin showed higher yield than the control plot (without treatment) (Table 6).

Table 5. Chemical control of bacterial of halo blight (BHB), caused by Pseudomonas syringae pv. garcae, coffee leaf rust (CLR), caused by Hemileia vastatrix, and brown leaf spot (BLS), caused by Boeremia exigua var. coffeae, in a coffee (cultivar Mundo Novo) plantation in the first experiment carried out in the municipality of Caconde, São Paulo State, Brazil, in the 2009-2010 harvest.

\begin{tabular}{|c|c|c|c|c|c|c|c|}
\hline \multirow{2}{*}{ Treatments } & \multirow{2}{*}{$\begin{array}{c}\text { BHB } \\
\text { Incidence in } \\
\text { the branches } \\
(\%)^{1}\end{array}$} & \multicolumn{5}{|c|}{ Incidence in the leaves (\%) } & \multirow{2}{*}{$\begin{array}{c}\text { Yield bags } \\
(60 \mathrm{~kg}) / \mathrm{ha}^{5} \\
09 / 06 / 2010\end{array}$} \\
\hline & & $\begin{array}{c}\text { BHB }^{2} \\
05 / 13 / 2010 \\
01 / 05 / 2010\end{array}$ & $\begin{array}{c}\text { CLR }^{3} \\
05 / 13 / 2010 \\
04 / 20 / 2010\end{array}$ & $\begin{array}{c}\text { BLS }^{4} \\
05 / 13 / 2010\end{array}$ & & & \\
\hline 1. Control & $74.4 a^{6}$ & $68.5 a^{6}$ & $28.7 a^{6}$ & $34.3 a^{6}$ & $47.1 \mathrm{a}^{6}$ & $12.9 a^{6}$ & $52.5 b^{6}$ \\
\hline 2. Kasugamycin + Silicone adhesive & $67.5 \mathrm{a}$ & $51.0 \mathrm{~b}$ & $21.9 \mathrm{a}$ & $27.4 \mathrm{a}$ & $28.4 \mathrm{~b}$ & $12.8 \mathrm{a}$ & $46.9 \mathrm{~b}$ \\
\hline $\begin{array}{l}\text { 3. Kasugamycin }(1.5 \mathrm{~L} / \mathrm{ha})+\text { Copper } \\
\text { hydroxyde + Silicone adhesive }\end{array}$ & $64.4 \mathrm{a}$ & $47.2 \mathrm{~b}$ & $28.1 \mathrm{a}$ & $19.4 \mathrm{a}$ & $28.2 \mathrm{~b}$ & $12.2 \mathrm{a}$ & $61.7 \mathrm{~b}$ \\
\hline 4. Copper hydroxide + Vegetal oil & $67.2 \mathrm{a}$ & $51.3 \mathrm{~b}$ & $15.6 \mathrm{a}$ & $24.7 \mathrm{a}$ & $25.0 \mathrm{~b}$ & 7.9 a & $53.4 \mathrm{~b}$ \\
\hline 5. Copper hydroxide + Mineral oil & $69.7 \mathrm{a}$ & $52.9 \mathrm{~b}$ & $19.3 \mathrm{a}$ & $26.1 \mathrm{a}$ & $29.0 \mathrm{~b}$ & $14.1 \mathrm{a}$ & $60.8 \mathrm{~b}$ \\
\hline $\begin{array}{l}\text { 6. Copper hydroxide + Silicone Adhe- } \\
\text { sive }\end{array}$ & $61.6 \mathrm{a}$ & $35.5 \mathrm{~b}$ & $18.8 \mathrm{a}$ & $23.9 \mathrm{a}$ & $28.2 \mathrm{~b}$ & $15.3 \mathrm{a}$ & $68.1 \mathrm{a}$ \\
\hline 7. Copper hydroxide + ASM ( $50 \mathrm{~g} / \mathrm{ha}$ ) & $49.1 \mathrm{a}$ & $34.5 \mathrm{~b}$ & $19.3 \mathrm{a}$ & $19.0 \mathrm{a}$ & $29.2 \mathrm{~b}$ & $8.4 \mathrm{a}$ & $79.7 \mathrm{a}$ \\
\hline 8. Copper oxychloride ( $4.0 \mathrm{~kg} / \mathrm{ha})$ & $67.2 \mathrm{a}$ & $47.5 \mathrm{~b}$ & $18.9 \mathrm{a}$ & $29.2 \mathrm{a}$ & $27.0 \mathrm{~b}$ & $12.4 \mathrm{a}$ & $82.1 \mathrm{a}$ \\
\hline $\begin{array}{l}\text { 9. Acibenzolar-S-Methyl (ASM)( } 25 \mathrm{~g} / \\
\text { ha) }\end{array}$ & $74.1 \mathrm{a}$ & $71.6 \mathrm{a}$ & $20.3 \mathrm{a}$ & $36.3 \mathrm{a}$ & $31.2 \mathrm{~b}$ & $11.6 \mathrm{a}$ & $53.4 \mathrm{~b}$ \\
\hline 10. Acibenzolar-S-Methyl (50g/ha) & $67.8 \mathrm{a}$ & $60.5 \mathrm{a}$ & $19.8 \mathrm{a}$ & $33.4 \mathrm{a}$ & 28.7 b & $10.4 \mathrm{a}$ & $54.1 \mathrm{~b}$ \\
\hline CV (\%) & 19,7 & 26.7 & 40.2 & 40.4 & 22.6 & 27.1 & 20.5 \\
\hline
\end{tabular}

${ }^{1} \mathrm{BHB}$ incidence in the branches - evaluated in 10 branches per plant in the upper third of the plant canopy. Branches with BHB symptoms in the first or the second pairs of leaves or recent dieback were counted as infected. ${ }^{2} \mathrm{BHB}$ incidence - evaluated in 80 leaves per plot collected from the second and third pairs of leaves in the medium third of the plant canopy. ${ }^{3} \mathrm{CLR}$ incidence - evaluated in 80 leaves per plot collected from the second and third pairs of leaves in the medium third of the plant canopy. ${ }^{4} \mathrm{BLS}$ incidence - evaluated in 80 leaves per plot collected from the second and third pairs of leaves in the medium third of the plant canopy. ${ }^{5}$ Yield per plot in $60 \mathrm{~kg}$ bags of dry coffee. ${ }^{6}$ Media followed by the same letter are not different by the Scott-Knott test at $5 \%$ probability. 
Table 6. Chemical control of bacterial of halo blight (BHB) caused by Pseudomonas syringae pv. garcae, coffee leaf rust (CLR) caused by Hemileia vastatrix, and brown leaf spot (BLS) caused by Boeremia exigua var. coffe$a e$, in a coffee (cultivar Mundo Novo) plantation in the second experiment carried out in the municipality of Caconde, São Paulo State, Brazil, in the 2009-2010 harvest.

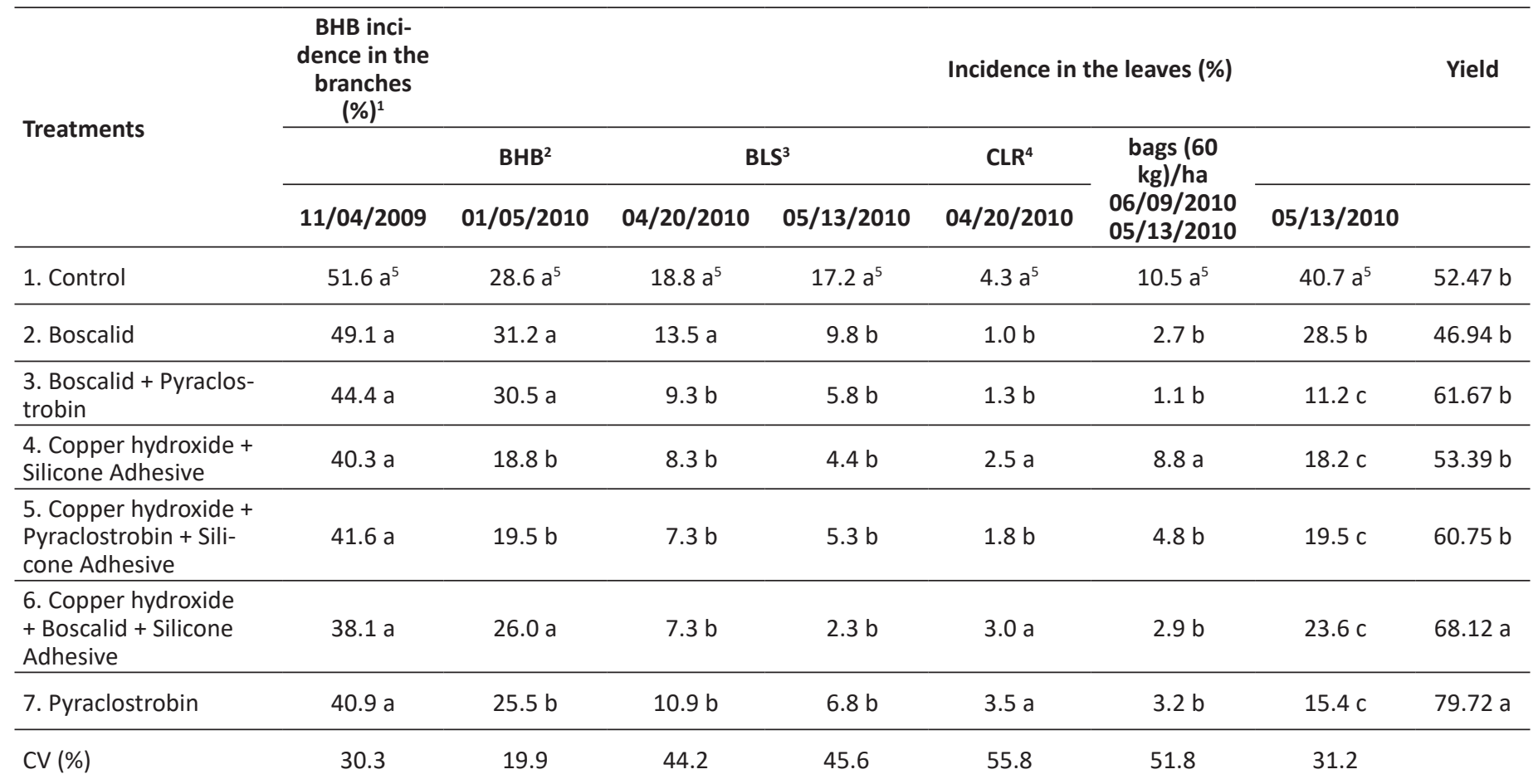

${ }^{1} \mathrm{BHB}$ incidence in the branches - evaluated as the percentage of new branches or new leaves in the branches of the upper third of the coffee plant canopy showing disease symptoms. ${ }^{2} \mathrm{BHB}$ incidence in the leaves -evaluated in 100 leaves per plot collected from the first and second pairs of leaves in the upper third of the plant canopy. ${ }^{4} \mathrm{CLR}$ incidence in the leaves - evaluated in 100 leaves per plot collected from the third and fourth pairs of leaves in the mid-third of the plant canopy. ${ }^{3}$ BLS incidence in the leaves - evaluated in 100 leaves per plot collected from the second and third pairs of leaves in the mid-third of the plant canopy. ${ }^{4} \mathrm{Means}$ followed by the same letter are not different by the Scott-Knott test at $5 \%$ probability.

Rains started in August $(66.2 \mathrm{~mm})$ in Caconde and increased until December 2009 (420.8 $\mathrm{mm})$, a very rainy month, decreasing in the subsequent months from January $(330.8 \mathrm{~mm})$ to April 2010 (51.6 mm). In the 2009/2010 harvest, rainfall amounted to $1,855.8 \mathrm{~mm}$ in Caconde. The Tmax and Tmin increased from August $\left(25.37^{\circ} \mathrm{C}\right.$ and $12.42^{\circ} \mathrm{C}$, respectively) until November $2009\left(29.69^{\circ} \mathrm{C}\right.$ and $19.62^{\circ} \mathrm{C}$, respectively) and were similar until March $2010\left(29.21^{\circ} \mathrm{C}\right.$ and $18.63^{\circ} \mathrm{C}$, respectively), decreasing afterward (Figure 1). Bacterial halo blight incidence in the branches was very high in November 2009 in the first experiment and decreased in the subsequent evaluations. Levels of BHB were lower in the second experiment in all evaluations probably because it was in a part of the experimental site less subject to strong winds.

In the first experiment carried out in Altinópolis, all treatments reduced BHB incidence in the branches in the first and second evaluations. However, the treatments showed no effect in the evaluation in April 2010, two months after the last application of the chemicals. Moreover, all treatments reduced BLS incidence in the branches, but treatment with copper hydroxide + boscalid + silicone adhesive was more effective. All treatments reduced BES incidence in the leaves of the upper third of the plant canopy, but treatments with copper hydroxide + silicone adhesive or metiran + pyraclstrobin were less effective. All treatments reduced BLS incidence in leaves; however, treatments with boscalid or pyraclostrobin were more effective. All treatments reduced CLR incidence, except for the treatments with methiran + pyraclostrobin and copper hydroxide + methiran + pyraclostrobin (Table 7).

In August 2009, the incidence of rains in Altinópolis $(27.1 \mathrm{~mm}$ ) was lower than in Caconde (66.2 $\mathrm{mm}$ ); nevertheless, the rains were more regular in the subsequent months, varying from $129.5 \mathrm{~mm}$ in September to $421.9 \mathrm{~mm}$ in January 2010, decreasing in the subsequent months. The total precipitation in the 2009/2010 harvest was $1,901.4 \mathrm{~mm}$. The average Tmax and Tmin increased from August $\left(25.8^{\circ} \mathrm{C}\right.$ and $15.2^{\circ} \mathrm{C}$ for Tmax and Tmin, respective- 
ly) until November $\left(28.9^{\circ} \mathrm{C}\right.$ and $19.7^{\circ} \mathrm{C}$, respectively) and were similar from November until March, when temperatures began to decrease. Bacterial halo blight incidence in the branches was lower in Altinópolis than in Caconde, increasing until January 2010 and decreasing in April 2010 (Figure 1).

The results of $\mathrm{BHB}$ chemical control in the experiment carried out in 2010/2011 were similar to those in 2009/2010. All treatments reduced disease incidence, but the treatment with copper phosphite was less effective in the first and third evaluations. In the second evaluation, in January 2011, treatments with copper hydroxide + pyraclostrobin + boscalid and with copper phosphite were less effective for disease control in the first AUDPC. In the second AUDPC, all treatments controlled BHB, but they were more effective than copper phosphite. As observed in previous experiments, only treatments with boscalid reduced BLS incidence in the leaves and branches (Table 8). We did not observe any effect on CLR control, and BES incidence was higher in treatments with copper hydroxide + silicone adhesive, copper hydroxide + boscalid + pyraclostrobin + silicone adhesive and copper phosphite in the evaluation carried out in July 2011 (Table 8).

In August 2010, there was no precipitation in Altinópolis. However, rainfall increased from September $(91.2 \mathrm{~mm}$ ) until December of the same year (252.1 $\mathrm{mm}$ ), and the total rainfall of the 2010/2011 harvest was $1,551.1 \mathrm{~mm}$. The Tmax and Tmin increased from August $\left(27.1^{\circ} \mathrm{C}\right.$ and $15.3^{\circ} \mathrm{C}$, respectively) to December $2010\left(28.6^{\circ} \mathrm{C}\right.$ and $19.4^{\circ} \mathrm{C}$, respectively) and remained similar until March 2011 $\left(25.8^{\circ} \mathrm{C}\right.$ and $18.8^{\circ} \mathrm{C}$ respectively), decreasing afterward. The rains returned in August 2011 (37.8 mm), but precipitation was very low in September (8.4 $\mathrm{mm}$ ), increasing from October until December 2011 ( $295.5 \mathrm{~mm}$ ). Bacterial halo blight incidence was very high in December 2010, decreasing until May 2011 and increasing again from September to December 2011 (Figure 2).

All treatments with the CBACs, copper hy- droxide and copper oxychloride reduced BHB incidence in Caconde. Although the first application of the chemicals was in September, the treatments were statistically different only in January, after three applications. However, the treatments were not effective in April, four months after the last application (Table 10). Similar results were also observed in Altinópolis in 2009/2010 and in 2010/2011, where all treatments with copper hydroxide reduced $\mathrm{BHB}$ incidence (Tables 11, 12). In Altinópolis, disease control was observed with only one application of CBACs, possibly because the products had a better distribution in the plant canopy with the mechanized pulverization. In 2010/2011, despite the last application in May 2011, a residual effect of the treatments was observed until December, possibly because precipitation was lower in this period than in December-January. The use of kasugamycin, pyraclostrobin and copper phosphite also reduced $\mathrm{BHB}$ incidence (Tables 10 and 12, respectively). However, no synergistic effect was observed by mixing kasugamycin or pyraclostrobin with copper hydroxide (Tables 10 and 11).

Copper based antimicrobial compounds were effective to control CLR (Tables 10 and 11), as well as treatments with boscalid, pyraclostrobin, boscalid + pyraclostrobin (Table 10) and methyran + pyraclostrobin (Table 11) in Caconde and Altinópolis in the 2010/2011 harvest, possibly because these treatments reduced the initial inoculum of the disease. In the last experiment, CLR incidence was very low in the experimental site and no differences between the treatments were observed (Table 9).

Treatments with boscalid (Tables 10, 11, and 12) or in some experiments with pyraclostrobin (Tables 10 and 11 ) reduced BLS incidence in both localities. Control of BES, caused by Cercospora coffeicola, was obtained with copper hydroxide alone or mixed with other products only in the first experiment in Altinópolis (Table 11). In the other experiments, the products tested did not provide BES control (Table 11). 
Table 7. Chemical control of bacterial of halo blight (BHB) caused by Pseudomonas syringae pv. garcae, coffee leaf rust (CLR) caused by Hemileia vastatrix, brown eye spot (BES) caused by Cercospora coffeicola, and brown leaf spot (BLS) caused by Boeremia exigua var. coffeae, in a coffee (cultivar Mundo Novo) plantation in the municipality of Altinópolis, São Paulo State, Brazil, in the 2009/2010 season.

\begin{tabular}{|c|c|c|c|c|c|c|c|}
\hline \multirow{3}{*}{ Treatments } & \multicolumn{5}{|c|}{ Incidence in the branches (\%) } & \multicolumn{2}{|c|}{ Incidence in the leaves (\%) } \\
\hline & & BHB $^{1}$ & & BLS $^{2}$ & BES $^{3}$ & $\mathrm{CLR}^{4}$ & $\mathrm{BLS}^{5}$ \\
\hline & $12 / 22 / 2009$ & $01 / 13 / 2010$ & $04 / 23 / 2010$ & $04 / 23 / 2010$ & $04 / 23 / 2010$ & $04 / 23 / 2010$ & $04 / 23 / 2010$ \\
\hline 1. Control & $25.9 a^{6}$ & $31.3 \mathrm{a}$ & $23.3 \mathrm{a}$ & $60.8 \mathrm{a}$ & $19.2 \mathrm{a}$ & $21.6 \mathrm{a}$ & $23.5 \mathrm{a}$ \\
\hline $\begin{array}{l}\text { 2. Copper hydroxide + Silicone } \\
\text { Adhesive }\end{array}$ & $13.5 \mathrm{~b}$ & $18.1 \mathrm{~b}$ & $13.3 \mathrm{a}$ & $36.3 \mathrm{~b}$ & $7.1 \mathrm{~b}$ & $3.2 \mathrm{~b}$ & $14.7 \mathrm{~b}$ \\
\hline 3. Copper hydroxide + Mineral oil & $8.9 \mathrm{~b}$ & $26.4 \mathrm{a}$ & $12.5 \mathrm{a}$ & $43.3 \mathrm{~b}$ & $2.1 \mathrm{c}$ & $3.0 \mathrm{~b}$ & $17.0 \mathrm{~b}$ \\
\hline $\begin{array}{l}\text { 4. Copper hydroxide + } \\
\text { Kasugamycin + Silicone Adhesive }\end{array}$ & $15.5 \mathrm{~b}$ & $15.1 \mathrm{~b}$ & $11.7 \mathrm{a}$ & $39.2 \mathrm{~b}$ & $3.8 \mathrm{c}$ & $3.1 \mathrm{~b}$ & $19.6 \mathrm{~b}$ \\
\hline $\begin{array}{l}\text { 5. Copper hydroxide + } \\
\text { Pyraclostrobin + Mineral oil }\end{array}$ & $16.0 \mathrm{~b}$ & $17.0 \mathrm{~b}$ & $10.0 \mathrm{a}$ & $38.8 \mathrm{~b}$ & $1.3 \mathrm{c}$ & $0.9 \mathrm{~b}$ & $17.0 \mathrm{~b}$ \\
\hline $\begin{array}{l}\text { 6. Copper hydroxide + Boscalid + } \\
\text { Mineral oil }\end{array}$ & $18.0 \mathrm{~b}$ & $21.9 \mathrm{a}$ & $13.3 \mathrm{a}$ & $23.8 \mathrm{c}$ & $5.8 \mathrm{c}$ & $6.7 \mathrm{~b}$ & $9.9 \mathrm{~b}$ \\
\hline 8. Metiram + Pyraclostrobin & $14.9 \mathrm{~b}$ & $22.8 \mathrm{a}$ & $13.3 \mathrm{a}$ & $45.8 \mathrm{~b}$ & $7.5 \mathrm{~b}$ & $1.3 \mathrm{~b}$ & $24.0 \mathrm{a}$ \\
\hline $\begin{array}{l}\text { 9. Copper hydroxide + Metiram + } \\
\text { Pyraclostrobin + Mineral oil }\end{array}$ & $15.9 \mathrm{~b}$ & $18.6 \mathrm{~b}$ & $16.7 \mathrm{a}$ & $37.1 \mathrm{~b}$ & $3.3 \mathrm{c}$ & $1.4 \mathrm{~b}$ & $21.2 \mathrm{a}$ \\
\hline $\begin{array}{l}\text { 10. Copper hydroxide + } \\
\text { Benzalkonium chloride }\end{array}$ & $17.4 \mathrm{~b}$ & $16.6 \mathrm{~b}$ & $13.3 \mathrm{a}$ & $36.2 \mathrm{~b}$ & $4.2 \mathrm{c}$ & $2.6 \mathrm{~b}$ & $16.0 \mathrm{~b}$ \\
\hline CV (\%) & 30.3 & 28.9 & 17.1 & 10.5 & 21.2 & 23.1 & 12.6 \\
\hline
\end{tabular}

${ }^{1} \mathrm{BHB}$ incidence in the branches - evaluated as the percentage of new branches or leaves in the first and second pair of leaves showing disease symptoms in branches of the upper third of the coffee plant canopy. ${ }^{2} \mathrm{BLS}$ incidence in the branches - evaluated as the percentage of new branches or leaves in the first and second pair of leaves showing disease symptoms in branches of the upper third of the coffee plant canopy. ${ }^{3} \mathrm{BES}$ incidence in the leaves -evaluated in 100 leaves per plot collected from the first and second pairs of leaves in the upper third of the plant canopy. ${ }^{4} \mathrm{CLR}$ incidence in the leaves - evaluated in 100 leaves per plot collected from the third and fourth pairs of leaves in the middle third of the plant canopy. ${ }^{5} \mathrm{BLS}$ incidence in the leaves - evaluated in 100 leaves per plot collected from the second and third pairs of leaves in the middle third of the plant canopy. ${ }^{6}$ Means followed by the same letter are not different by the Scott-Knott test at $5 \%$ probability.

Table 8. Chemical control of bacterial of halo blight (BHB) caused by Pseudomonas syringae pv. garcae, in a coffee (cultivar Mundo Novo) plantation in the municipality of Altinópolis, São Paulo State, Brazil, in the 2010/2011 season.

\begin{tabular}{|c|c|c|c|c|c|c|c|c|}
\hline \multirow{2}{*}{ Treatments } & \multicolumn{8}{|c|}{ BHB incidence in the branches ${ }^{1}(\%)$} \\
\hline & $12 / 14 / 2010$ & $01 / 24 / 2011$ & $03 / 29 / 2011$ & $05 / 28 / 2011$ & AACPD1 & 09/03/2011 & $12 / 07 / 2011$ & AACPD2 \\
\hline 1. Control & $70.6 a^{2}$ & $36.5 a^{2}$ & $25.2 \mathrm{a}^{2}$ & $31.8 a^{2}$ & $4,738.3 a^{2}$ & $65.8 a^{2}$ & $79.3 a^{2}$ & $15,128.3^{2} a$ \\
\hline $\begin{array}{l}\text { 2. Copper hydroxyde + Silicone } \\
\text { Adhesive }\end{array}$ & $22.2 \mathrm{c}$ & $12.0 \mathrm{~b}$ & $7.8 \mathrm{c}$ & $15.3 \mathrm{~b}$ & $1,769.6 \mathrm{c}$ & $22.3 \mathrm{c}$ & $50.0 \mathrm{~b}$ & $6,783.0 \mathrm{c}$ \\
\hline $\begin{array}{l}\text { 3. Copper hydroxyde + Pyra- } \\
\text { clostrobin + Silicone Adhesive }\end{array}$ & $21.8 \mathrm{c}$ & $12.5 \mathrm{~b}$ & $5.8 \mathrm{c}$ & $8.8 \mathrm{~b}$ & $1,, 619.1 \mathrm{c}$ & $23.0 \mathrm{c}$ & $42.8 \mathrm{~b}$ & $5,150.0 \mathrm{c}$ \\
\hline $\begin{array}{l}\text { 4. Copper hydroxyde + Boscalid } \\
+ \text { Silicone Adhesive }\end{array}$ & $25.9 \mathrm{c}$ & $12.5 \mathrm{~b}$ & $8.3 \mathrm{c}$ & $12.8 \mathrm{~b}$ & $2,193.1 \mathrm{c}$ & $21.8 \mathrm{c}$ & $44.0 \mathrm{~b}$ & $6,638.8 c$ \\
\hline $\begin{array}{l}\text { 5. Copper hydroxyde + Pyra- } \\
\text { clostrobin + Boscalid + Silicone } \\
\text { Adhesive }\end{array}$ & $41.5 \mathrm{~b}$ & $21.5 \mathrm{a}$ & $8.8 \mathrm{c}$ & $10.2 \mathrm{~b}$ & $2,723.9 \mathrm{~b}$ & $23.8 \mathrm{c}$ & $55.5 \mathrm{~b}$ & $7,258.0 \mathrm{c}$ \\
\hline 6. Copper phosphite & $47.5 \mathrm{~b}$ & $25.8 \mathrm{a}$ & $15.8 \mathrm{~b}$ & $18.3 \mathrm{~b}$ & $3,129.5 \mathrm{~b}$ & $41.3 \mathrm{~b}$ & $64.0 \mathrm{a}$ & $10,243.4 \mathrm{~b}$ \\
\hline CV (\%) & 30.3 & 19.6 & 34.4 & 35.0 & 18.3 & 24.3 & 18.8 & 14.9 \\
\hline
\end{tabular}

${ }^{1} \mathrm{BHB}$ incidence in the branches - evaluated as the percentage of new branches or leaves in the first and second pairs of leaves showing disease symptoms in branches of the upper third of the coffee plant canopy. ${ }^{2}$ Means compared by the Scott-Knott at $5 \%$ probability. 
Table 9. Chemical control of brown leaf spot (BLS) caused by Boeremia exigua pv. coffea, coffee leaf rust (CLR) caused by Hemileia vastatrix and brown eye spot (BES) caused by Cercospora coffeicola in a coffee (cultivar Mundo Novo) plantation in the municipality of Altinópolis, São Paulo, Brazil, in the 2010/2011 season.

\begin{tabular}{|c|c|c|c|c|c|c|}
\hline \multirow{3}{*}{ Treatments } & \multicolumn{3}{|c|}{ BLS } & CLR & \multicolumn{2}{|c|}{ BES } \\
\hline & \multicolumn{2}{|c|}{ Incidence in the leaves ${ }^{1}(\%)$} & \multirow{2}{*}{$\begin{array}{c}\text { Incidence } \\
\text { in the bran- } \\
\text { ches }^{2}(\%)\end{array}$} & \multicolumn{3}{|c|}{ Incidence in the leaves ${ }^{1}(\%)$} \\
\hline & $03 / 29 / 2011$ & $05 / 28 / 2011$ & & $05 / 28 / 2011$ & $03 / 29 / 2011$ & $05 / 28 / 2011$ \\
\hline 1. Control & $21.3 a^{3}$ & $15.5 \mathrm{a}$ & $21.5 \mathrm{a}$ & $1.07 \mathrm{a}^{4}$ & 4.9 a & $3.27 b$ \\
\hline 2. Copper hydroxyde + Silicone Adhesive & $20.3 \mathrm{a}$ & $12.7 \mathrm{a}$ & $18.8 \mathrm{a}$ & $1.24 \mathrm{a}$ & $2,3 \mathrm{a}$ & $6.25 \mathrm{a}$ \\
\hline $\begin{array}{l}\text { 3. Copper hydroxyde + Pyraclostrobin + Silicone } \\
\text { Adhesive }\end{array}$ & $18.8 \mathrm{a}$ & $14.3 \mathrm{a}$ & 19.8 a & $1.04 \mathrm{a}$ & 3,9 a & $2.29 \mathrm{~b}$ \\
\hline $\begin{array}{l}\text { 4. Copper hydroxyde + Boscalid + Silicone Adhe- } \\
\text { sive }\end{array}$ & $8.5 \mathrm{~b}$ & $7.7 \mathrm{~b}$ & $15.5 \mathrm{~b}$ & $1.29 \mathrm{a}$ & $4,8 \mathrm{a}$ & $4.19 \mathrm{~b}$ \\
\hline $\begin{array}{l}\text { 5. Copper hydroxyde + Pyraclostrobin + Boscalid + } \\
\text { Silicone Adhesive }\end{array}$ & $7.0 \mathrm{~b}$ & $7.5 \mathrm{~b}$ & $12.2 \mathrm{~b}$ & $0.93 a$ & 4,5 a & $6.81 \mathrm{a}$ \\
\hline \multirow[t]{2}{*}{ 6. Copper phosphite } & $18.7 \mathrm{a}$ & $15.8 \mathrm{a}$ & $17.3 \mathrm{a}$ & $1.85 \mathrm{a}$ & $4,5 \mathrm{a}$ & 10.85 a \\
\hline & 33.5 & 29.3 & 14.4 & 27.9 & 47,7 & 54.8 \\
\hline
\end{tabular}

${ }^{1}$ Incidence in the leaves - evaluated in 100 leaves per plot collected from the second or third pairs of leaves in the middle third of the plant canopy. ${ }^{2} \mathrm{BLS}$ - incidence in the branches - evaluated as the percentage of new branches or leaves in the first and second pairs of leaves showing disease symptoms in branches of the upper third of the coffee plant's canopy. ${ }^{3}$ Means compared by the Scott-Knott test at $5 \%$ probability. ${ }^{4}$ Data transformed by the formula $(x+1)^{1 / 2}$

A
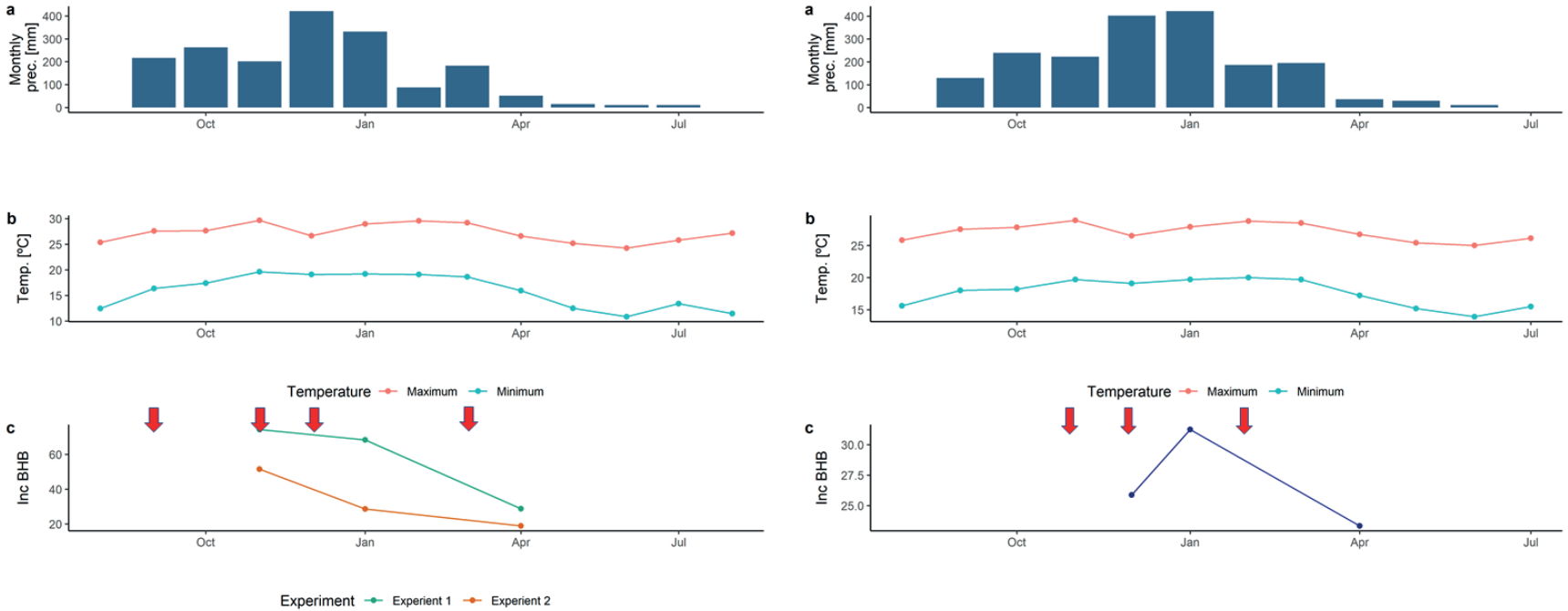

Figure 1. $T$ max, $T$ min (a); Precipitation (b), and incidence of bacterial halo blight (BHB) caused by Pseudomonas syringae pv. garcae (c) in the 2009-2010 harvest in Caconde (A) and Altinópolis (B), São Paulo State, Brazil. Arrows refer to the dates of applications. 

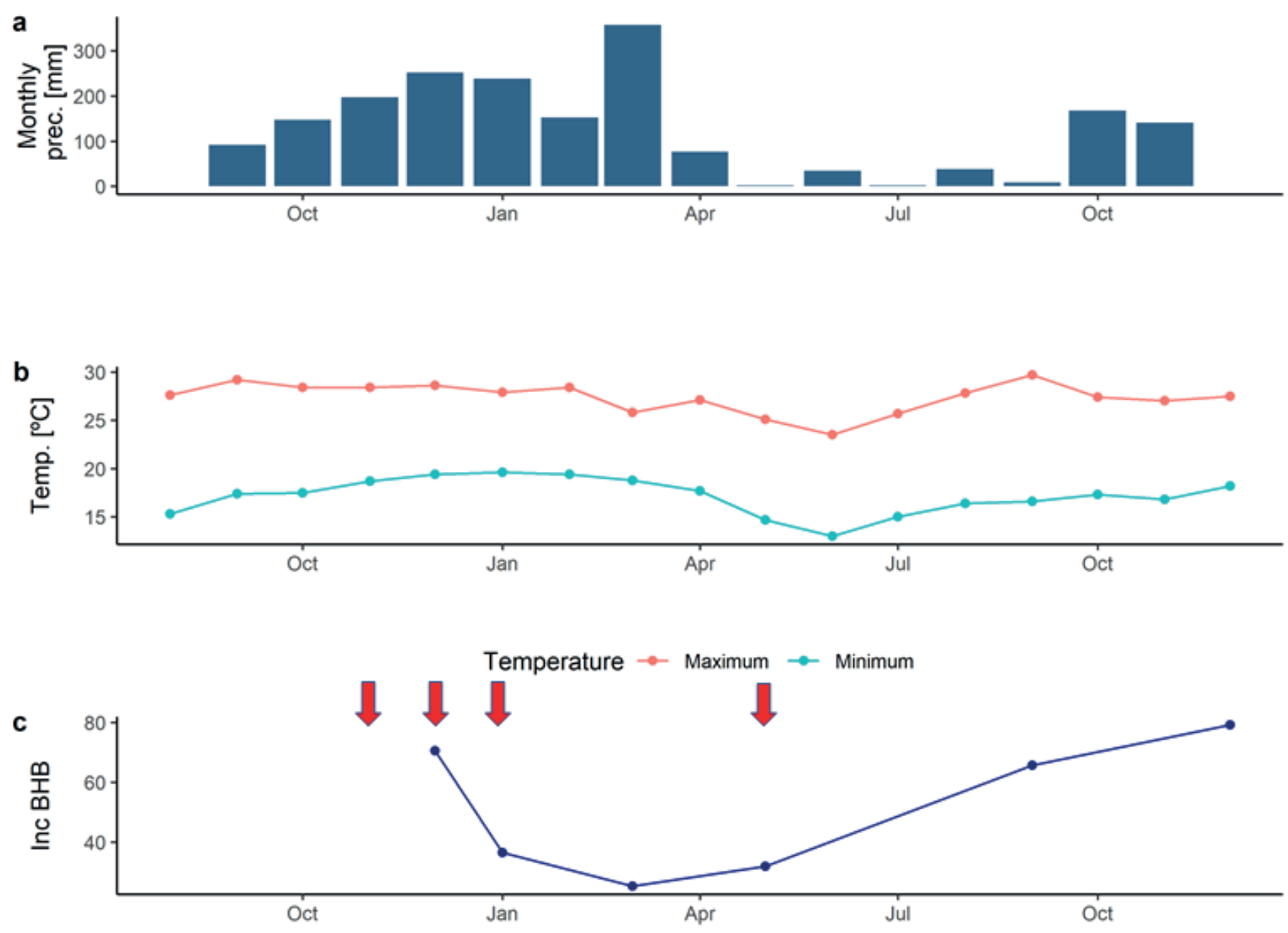

Figure 2. $T$ max, $T$ min (a); Precipitation (b), and incidence of bacterial halo blight (BHB) caused by Pseudomonas syringae pv. garcae (c) in the 2010-2011 harvest in Altinópolis, São Paulo State, Brazil. Arrows refer to the dates of applications. 
Table 10. Effect of treatments on the control of bacterial of halo blight (BHB) caused by Pseudomonas syringae pv. garcae, coffee leaf rust (CLR) caused by Hemileia vastatrix, and brown leaf spot (BLS) caused by Boeremia exigua var. coffeae, in the first and second experiments in a coffee (cultivar Mundo Novo) cultivation in the municipality of Caconde, São Paulo State, Brazil, in the 2009-2010 harvest.

\begin{tabular}{|c|c|c|c|c|c|c|c|c|c|c|}
\hline \multirow[t]{2}{*}{ Treatments } & \multicolumn{4}{|c|}{ Applications } & \multicolumn{3}{|c|}{$\mathrm{BHB}^{1}$} & \multirow{2}{*}{$\begin{array}{l}\text { BHB }^{2} \\
\text { May }\end{array}$} & \multirow{2}{*}{$\begin{array}{l}\text { CLR }^{3} \\
\text { May }\end{array}$} & \multirow{2}{*}{$\begin{array}{l}\text { BLS }^{4} \\
\text { May }\end{array}$} \\
\hline & Sep & Nov & Dec & Apr & Nov & Jan & Apr & & & \\
\hline Copper hydroxide + Silicone Adhesive & $x$ & $x$ & $x$ & $x$ & - & + & + & - & + & - \\
\hline Copper hydroxide + Vegetal oil & $x$ & $x$ & $x$ & $x$ & - & + & - & - & + & - \\
\hline Copper hydroxide + Mineral oil & $x$ & $\mathrm{x}$ & $x$ & $\mathrm{x}$ & - & + & - & - & + & - \\
\hline Copper hydroxyde + Silicone adhesive + Kasugamycin & $x$ & $x$ & $x$ & $x$ & - & + & - & - & + & - \\
\hline Copper hydroxide + Acibenzolar-S-Methyl (50 g/ha) & $\mathrm{x}$ & $\mathrm{x}$ & $\mathrm{x}$ & $\mathrm{x}$ & - & + & - & - & + & - \\
\hline Copper hydroxide + Pyraclostrobin + Silicone Adhesive & $x$ & $x$ & $x$ & $x$ & - & + & + & - & + & + \\
\hline Copper hydroxide + Boscalid + Silicone Adhesive & $\mathrm{x}$ & $\mathrm{x}$ & $\mathrm{x}$ & $\mathrm{x}$ & - & + & + & - & + & + \\
\hline Copper oxychloride & $x$ & $x$ & $x$ & $\mathrm{x}$ & - & + & - & - & + & - \\
\hline Kasugamycin + Silicone adhesive & $x$ & $x$ & $x$ & $x$ & - & + & - & - & + & - \\
\hline Acibenzolar-S-Methyl ( $25 \mathrm{~g} / \mathrm{ha})$ & $x$ & $x$ & $x$ & $\mathrm{x}$ & - & - & - & - & + & - \\
\hline Acibenzolar-S-Methyl $(50 \mathrm{~g} / \mathrm{ha})$ & $x$ & $x$ & $x$ & $x$ & - & - & - & - & + & - \\
\hline Boscalid & $x$ & $x$ & $x$ & $x$ & - & - & - & - & + & + \\
\hline Pyraclostrobin & $x$ & $x$ & $x$ & $\mathrm{x}$ & - & + & + & - & + & + \\
\hline Boscalid + Pyraclostrobin & $x$ & $x$ & $x$ & $x$ & - & - & + & - & + & + \\
\hline
\end{tabular}

${ }^{1} \mathrm{BHB}$ incidence in the branches - evaluated in 10 branches per plant on the upper third of the plant canopy. Branches with BHB symptoms in the first or the second pairs of leaves or recent dieback were counted as infected. ${ }^{2}$ BHB incidence - evaluated in 80 leaves per plot collected from the second and third pairs of leaves in the medium third of the plant canopy. ${ }^{3} \mathrm{CLR}$ incidence - evaluated in 80 leaves per plot collected from the second and third pairs of leaves in the medium third of the plant canopy. ${ }^{4}$ BLS incidence - evaluated in 80 leaves per plot collected from the second and third pairs of leaves in the medium third of the plant canopy.

Not effective treatment.

$+\quad$ Effective treatment.

Table 11. Effect of treatments in a coffee (cultivar Mundo Novo) plantation on the control of bacterial of halo blight (BHB) caused by Pseudomonas syringae pv. garcae, coffee leaf rust (CLR) caused by Hemileia vastatrix, and brown leaf spot (BLS) caused by Boeremia exigua var. coffeae, in the first experiment in the municipality of Altinópolis, São Paulo State, Brazil, in the 2009-2010 harvest.

\begin{tabular}{|c|c|c|c|c|c|c|c|c|c|c|}
\hline \multirow[t]{2}{*}{ Treatments } & \multicolumn{3}{|c|}{ Applications } & \multicolumn{3}{|c|}{ BHB $^{1}$} & \multirow{2}{*}{$\begin{array}{l}\text { BLS } \\
\text { Apr }\end{array}$} & \multirow{2}{*}{$\frac{\text { BES }}{\text { Apr }}$} & \multirow{2}{*}{$\begin{array}{l}\text { CLR }^{3} \\
\text { Apr }\end{array}$} & \multirow{2}{*}{$\begin{array}{l}\text { BLS } \\
\text { Apr }\end{array}$} \\
\hline & Nov & Dec & Feb & Dec & Jan & Apr & & & & \\
\hline Copper hydroxide + Silicone Adhesive & $\mathrm{x}$ & $x$ & $x$ & + & + & - & + & + & + & + \\
\hline Copper hydroxide + Mineral oil & $x$ & $x$ & $\mathrm{x}$ & + & - & - & + & + & + & ++ \\
\hline Copper hydroxyde + Silicone adhesive + Kasugamycin & $x$ & $\mathrm{x}$ & $x$ & + & + & - & + & + & + & ++ \\
\hline Copper hydroxide + Pyraclostrobin + Mineral oil & $\mathrm{x}$ & $x$ & $x$ & + & + & - & + & + & + & ++ \\
\hline Copper hydroxide + Boscalid + Mineral oil & $\mathrm{x}$ & $\mathrm{x}$ & $\mathrm{x}$ & + & - & - & ++ & + & + & ++ \\
\hline Copper hydroxide + Metiram + Pyraclostrobin + Mineral oil & $x$ & $x$ & $x$ & + & + & - & + & - & + & ++ \\
\hline Copper hydroxide +Benzalkonium chloride & $\mathrm{x}$ & $x$ & $x$ & + & + & - & + & + & + & ++ \\
\hline Metiram + Pyraclostrobin & $x$ & $x$ & $x$ & + & - & - & + & - & + & + \\
\hline
\end{tabular}

${ }^{1} \mathrm{BHB}$ incidence in the branches - evaluated in 10 branches per plant on the upper third of the plant canopy. Branches with BHB symptoms in the first or the second pairs of leaves or recent dieback were counted as infected. ${ }^{2} \mathrm{BHB}$ incidence - evaluated in 80 leaves per plot collected from the second and third pairs of leaves in the medium third of the plant canopy. ${ }^{3} \mathrm{CLR}$ incidence - evaluated in 80 leaves per plot collected from the second and third pairs of leaves in the medium third of the plant canopy. ${ }^{4} \mathrm{BLS}$ incidence - evaluated in 80 leaves per plot collected from the second and third pairs of leaves in the medium third of the plant canopy.

- Not effective treatment. $\quad+\quad$ Effective treatment.

Treatment more effective than the others. 
Table 12. Effect of treatments on the control of bacterial of halo blight (BHB) caused by Pseudomonas syringae pv. garcae, coffee leaf rust (CLR) caused by Hemileia vastatrix, and brown leaf spot (BLS) caused by Boeremia exigua pv. coffea, in the first experiment in a coffee (cultivar Mundo Novo) cultivation in the municipality of Altinópolis, São Paulo State, Brazil, in the 2010-2011 harvest.

\begin{tabular}{|c|c|c|c|c|c|c|c|c|c|c|c|c|c|c|}
\hline Treatments & & Applic & ations & & & & & $\mathrm{AB}^{1}$ & & & $\mathrm{BLS}^{2}$ & $\mathrm{CLR}^{3}$ & $\mathrm{BLS}^{4}$ & \\
\hline 1. Control & Nov & Dec & Jan & May & Dec & Jan & Mar & May & Sep & Dec & Mar & May & May & May \\
\hline Copper hydroxide + & $\mathbf{x}$ & $\mathbf{x}$ & $\mathbf{x}$ & $\mathbf{x}$ & ++ & + & ++ & + & ++ & + & - & - & - & - \\
\hline $\begin{array}{l}\text { Copper hydroxide + Pyraclostrobin + Silicone } \\
\text { adhesive }\end{array}$ & $\mathbf{x}$ & $\mathbf{x}$ & $\mathbf{x}$ & $\mathbf{x}$ & ++ & + & ++ & + & ++ & + & - & - & - & - \\
\hline $\begin{array}{l}\text { Copper hydroxide + Boscalid + Silicone adhe- } \\
\text { sive }\end{array}$ & $x$ & $\mathbf{x}$ & $\mathbf{x}$ & $x$ & ++ & + & ++ & + & ++ & + & + & + & - & - \\
\hline $\begin{array}{l}\text { Copper hydroxide + Pyraclostrobin + Boscalid } \\
+ \text { Silicone adhesive }\end{array}$ & $\mathbf{x}$ & $\mathbf{x}$ & $\mathbf{x}$ & $\mathbf{x}$ & + & - & ++ & + & ++ & + & + & + & - & - \\
\hline Copper phosphite & $\mathbf{x}$ & $\mathbf{x}$ & $\mathbf{x}$ & $\mathbf{x}$ & + & - & + & + & + & - & - & - & - & - \\
\hline
\end{tabular}

${ }^{1} \mathrm{BHB}$ incidence in the branches - evaluated in 10 branches per plant on the upper third of the plant canopy. Branches with BHB symptoms in the first or the second pairs of leaves or recent dieback were counted as infected. ${ }^{2} \mathrm{BLS}$ incidence - evaluated in 80 leaves per plot collected from the second and third pairs of leaves in the medium third of the plant canopy. ${ }^{3} \mathrm{CLR}$ incidence - evaluated in 80 leaves per plot collected from the second and third pairs of leaves in the medium third of the plant canopy. ${ }^{4}$ BLS incidence - evaluated in 80 leaves per plot collected from the second and third pairs of leaves in the medium third of the plant canopy.

Not effective treatment.

$+\quad$ Effective treatment.

Treatment more effective than the others.

\section{DISCUSSION}

In this study we showed that the treatments with the CBACs, copper hydroxide or copper oxychloride, with or without additives, reduced BHB incidence in all experiments in both localities. Similarly, in the Solai region in Kenya, copper hydroxide, cuprous oxide and copper oxychloride were effective to control BHB and coffee berry disease, caused by Colletotrichum coffeanum (KAIRU et al. 1985). KAI$\mathrm{RU}$ et al. (1991) observed that the treatment with copper hydroxide ( $35 \% \mathrm{Cu}$ ) at the dose of $7.0 \mathrm{~kg} /$ ha was more efficient for BHB and CDB control than treatments with other products containing smaller copper amounts. In Brazil, copper oxychloride was also effective for BHB control in coffee seedlings and in field conditions treatments with this CBAC showed lower dieback incidence in the branches caused by BLS and BHB (PATRICIO et al. 2008).

The constant application of CBACs can result in $\mathrm{Cu}$ accumulation in the soils, affecting populations of soil microorganisms and causing other collateral effects (LAMICHHANE et al. 2018). Here, we suggest three to four applications of CBACs per coffee crop cycle for BHB management. Copper hydroxide used at $2.5 \mathrm{~kg} / \mathrm{ha}$ could reach 2.625 to $3.5 \mathrm{~kg}$ of metallic $\mathrm{Cu} / \mathrm{ha}$; however, this amount is lower than that applied in other cultures, such as citrus, for the control of citrus black spot (Phyllosticta citricarpa) and citrus scab (Elsinoe australis), of approximately $3.675 \mathrm{~kg} / \mathrm{ha}$. This amount could rise to $6.825 \mathrm{~kg} /$ ha with the occurrence of citrus canker (Xanthomonas citri subsp. citri) (AGROFIT 2021). Moreover, in previous studies, the amount of $\mathrm{Cu}$ applied per ha for BHB management was higher. KAIRU et al. (1985) applied 13 to 14 applications from March to November of $3.5 \mathrm{~kg}$ of $\mathrm{Cu}$ per ha and in two weeks intervals, comprising 15.9 to $17.5 \mathrm{~kg}$ of Cu per ha for the control of $\mathrm{BHB}$ and $\mathrm{CBD}$ in that condition. The authors observed that the treatments with copper hydroxide $(35 \% \mathrm{Cu})$ applied at the dose of $3.5 \mathrm{~kg} /$ ha was more effective than the treatment with 2.0 $\mathrm{kg} / \mathrm{ha}$. In Brazil, it appears that improving the timing of the applications could reduce the $\mathrm{Cu}$ amount applied per hectare.

In our study, the use of any CBACs mixed with additives (vegetable oil, mineral oil, or silicone adhesive) showed no phytotoxic effects on the flowers and pin-head berries. Other perennial crops, such as apple, pear, and citrus, have shown phytotoxicity of CBACs in the blooming phase, (LAMICHHANE et al. 2018). The $B H B$ incidence was smaller in the treatment with copper hydroxide added with silicone adhesive than with the mineral (in both experiments) or vegetal oil (in one experiment), although not statistically significant; therefore, silicone adhesive was included in the subsequent experiment in Alt- 
inópolis. This adjuvant may have improved the distribution of the copper particles in the coffee plant canopy, without adverse phytotoxic effects. BAIO et al. (2015) observed that silicone adhesive promoted the greatest reduction in the superficial tension as well as a better distribution of the spray solution on the leaves of soybean plants, when compared to other adjuvants, such as mineral or vegetable oil (BAIO et al. 2015).

The best treatment for the control of BHB in coffee seedlings was the antibiotic kasugamycin, with lower incidence and severity than the treatment with copper oxychloride (PATRICIO et al. 2008). However, in this work the antibiotic was effective to control BHB in the experiments carried out in Caconde, but it was not superior to the CBACs treatments. Probably, it was due to applications at longer intervals than in the seedlings, and kasugamycin has a lower residual effect than the CBACs. The combination of kasugamycin with copper hydroxyde showed no additional beneficial effect in the treatments in Caconde or Altinópolis (2009/2010). In another similar pathosystem, with artificial inoculations of Pseudomonas savastanoi pv. savastanoi, NGUYEN et al. (2018) did not find a higher level of control of olive knot applying kasugamycin mixed with copper oxychloride than with the copper oxychloride only treatment. However, there was some advantage in experiments with Cu resistant isolates (NGUYEN et al. 2018). VALLAD et al. (2010) observed that the association of kasugamycin and CBACs, as a tank-mix option, did not improve control of bacterial tomato spot, caused by four species of Xanthomonas: $X$. euvesicatoria, $X$. vesicatoria, $X$. perforans, and $X$. gardnerii.

In Caconde, the treatment with ASM alone did not promote BHB control; however, the mixture of ASM and copper hydroxide reduced BHB incidence and provided higher coffee yield than the control. ASM is a well-known resistant inducer of the benzothiazole group that can induce plant defense mechanisms through the salicylic acid pathway (CELLINI et al. 2014). In a similar pathosystem with Pseudomonas syringae pv. syringae in mango plants, CAZORLA et al. (2006) observed that ASM and combination of ASM and Bordeaux mixture were effective to control apical necrosis and lesions in flowers and buds. Similar results were obtained with the inoculation of two species of kiwi plants, Actinidia deliciosa and $A$. chinensis, with $P$. syringae pv. actinidae, causal agent of bacterial canker. ASM was more effective for cultivar $A$. deliciosa and disease control was related to the induction of defense resistance genes in the plants (CELLINI et al. 2014). PATRICIO et al. (2008) observed that ASM reduced BHB symptoms in coffee seedlings. However, in our present study under field conditions, ASM was effective only when mixed with copper hydroxide, combining products with two modes of action. This possibly occurred because environmental conditions were more extreme in the coffee crops, with high incidence of winds, and the application intervals were greater than in the seedlings.

In the experiment carried out in Altinópolis in 2010/2011, the treatment with copper phosphite reduced the $\mathrm{BHB}$ incidence, although less efficient than the treatments with copper hydroxide. COSTA et al. (2014) showed that phosphite could reduce severity of other diseases, such as CLR and BES, in coffee crops. Phosphite could also induce plant defense mechanisms by releasing superoxide, causing death of infected cells, and enhancing the accumulation of phenolic compounds (DANIEL \& GUEST 2006). Moreover, phosphite can inhibit pathogen growth, as demonstrated for a mutant of $P$. syringae resistant to the antibiotic rifampicin, Pseudomonas syringae Psp191R1 by BULTREYS et al. (2018). The authors reported that phosphite had a strong effect on in vitro growth of the pathogen, as well as on bacterial growth on the leaf surfaces, with a high acidic effect.

Treatments that included boscalid were the most effective for BLS control in our study. In Caconde (2009/2010), treatments with pyraclostrobin or mixtures of pyraclostrobin with boscalid were also effective for BLS control. The carboxamide boscalid is registered and widely used for the BLS management in Brazil (AGROFIT 2019). In another similar pathosystem, boscalid mixed with pyraclostrobin rapidly replaced strubilurin-only fungicides for the control of ascochyta blight, caused by Ascochyta rabie, in chickpeas (GAN et al. 2006) and gummy stem blight, caused by Didymella bryoniae, in cucurbits (KEINATH 2012), because carboxamide is from a different group than the QOi (strubilurins). In our stu$d y$, the fact that these fungicides were compatible with copper hydroxide is relevant because BHB may occur simultaneously with BLS (PATRICIO \& OLIVEIRA 2013). 
Brown eye spot, caused by C. coffeicola, was controlled by treatments with copper hydroxide and additives or pyraclostrobin or boscalid in the first experiment carried out in Altinópolis. This evaluation was carried out in April, when the fruits are fully formed but still immature, and two months after the last fungicide application. PATRICIO et al. (2008) also found that copper oxychoride and a strubilurin (azoystrobin) were also effective for BES control in coffee seedlings. In the last experiment in Altinópolis, none of the treatments promoted BES control, possibly because this evaluation was carried out four months after the last fungicide application and after the harvest, when the coffee plants are nutrient deprived. Brown eye spot is a disease in which host susceptibility is strongly influenced by nutritional deficiencies, especially $\mathrm{N}$ and K (PATRICIO \& OLIVEIRA 2013).

In this work, we observed that, in Brazil, BHB incidence in all experiments increased from September until December or January, with a subsequent reduction in the remaining months of the crop cycle. This is when physiological activities of the leaves are at their peak and susceptible flowers and pin-head berries are being formed, as observed by COSTA et al. (1957), when the disease was discovered in Brazil. In our study, treatments with copper hydroxide or copper oxychloride did not differ in terms of disease control. However, the treatments with copper hydroxide + silicone adhesive and copper oxychloride showed higher yields than other treatments in the experiment carried out in Caconde. Similar results were found in experiments to control BHB in Kenya (KAIRU et al. 1985, 1991). Nevertheless, in that country, CBACs controlled BHB and CDB and therefore the higher yields were due to the control of both diseases. In Brazil, we tend to apply chemical control of BHB only when the disease incidence is already high in the coffee crop, disregarding the crop cycle. We observed that the highest BHB incidences occurred when flowering and pin-head berries were being formed and that the application of control measures could reduce disease incidence and increase yield of infested coffee crops. The BHB treatments should be applied in August or September until December, and these treatments could still have a beneficial effect on CLR control.

The BHB incidence decreased in the summer, after a peak in December or January. This phenomenon may be attributed to higher temperatures that prevailed in these crops in the summer months, with the maximum average temperatures varying from $27.8^{\circ} \mathrm{C}$ to $28.8^{\circ} \mathrm{C}$ and the minimum varying from $19.7^{\circ} \mathrm{C}$ to $20^{\circ} \mathrm{C}$ (Figures 1 and 2 ). Moreover, the vigorous and rapid growth of coffee plants could make them less susceptible during this period. FREITAS (2017) reported that BHB severity in coffee seedlings was higher at temperatures ranging from $18^{\circ} \mathrm{C}$ to $24^{\circ} \mathrm{C}$, decreasing at higher temperatures.

The amount of rainfall during the experiments carried out in Kenya (KAIRU et al. 1985) for BHB and CDB control varied from 924 to $1,459 \mathrm{~mm}$. This volume was lower than the precipitation in the experimental areas in our study, which were $1,856 \mathrm{~mm}$ in the 2009/2010 harvest in Caconde and 1,901 and $1,551 \mathrm{~mm}$ in the 2009/2010 and 2010/2011 in Altinópolis, respectively. However, in Kenya, the rains were well distributed throughout the year, with two or three rainy seasons per year, and BHB incidence followed the rainfall pattern, increasing as the rains increased, from May to November (KAIRU et al. 1985, KAIRU et al. 1991). In the coffee producing areas in Brazil, the rains are concentrated from September or October until March, and the winter months are very dry. In Brazil, the rains seem to play an important role in the onset of BHB epidemics. Moreover, the incidence of winds and intense physiological activities in the coffee plants during the formation of flowers and pin-head berries are also possibly relevant to the disease epidemics. After the disease onset, the different amounts of precipitation during our experiments were not related to the disease incidence. In the experiments carried out in Caconde, the plots at higher altitudes of the experimental site, where the incidence of winds was higher, were more affected by BHB and showed lower yields. Similarly, KAIRU et al. (1991) observed that $\mathrm{BHB}$ chemical control was less effective when the disease incidence was very high, following a hailstorm. COSTA et al. (1957) demonstrated the influence of injuries in plant tissues and BHB incidence. The authors observed that inoculation of $P$. syringae $\mathrm{pv}$. garcae in seedlings subjected to artificial winds resulted in $100 \%$ BHB incidence, while only $8.33 \%$ of the non-wounded seedlings were infected (COSTA et al. 1957). Moreover, FREITAS (2017) reported that the BHB severity was not influenced by leaf wetness duration at different temperatures when the seedlings were wounded before inoculation and these seedlings showed BHB severity six-fold higher 
than non-wounded plants. On the other hand, more than 35.5 hours of leaf wetness were necessary for BHB to occur in non-wounded plants. FERNANDES et al. (2020) showed a positive correlation between injuries and BHB severity in coffee crops in Paraná State.

Although CBACs have multiple sites of action against plant pathogens, eventually their constant use in coffee crops could favor the growth of resistant populations of $P$. syringae pv. garcae, as observed for populations of $P$. syringae in apple, kiwifruit, tomato, plum and sweet cherry (LAMICHHANE et al. 2018). In our study, there was no synergism in the mixture of CBACs with the other products tested. However, mixtures with resistant inducers ASM, or copper phosphite, or kasugamycin could be a strategy to avoid lack of control of $P$. syringae pv. garcae populations resistant to $\mathrm{Cu}$. Reductions in the use of CBACs in coffee crops should be investigated in future studies that could include new resistant inducers or biological control agents.

Our study showed that BHB incidence in Brazil augments and reaches the peak in the spring months when the coffee plants are flowering, and the pin-head-berries are being formed. We showed that chemical control with CBACs and copper hydroxide mixed with additives, such as mineral or vegetable oil or silicone adhesive could be safely applied during this period. The CBACs could have a residual effect reducing CLR incidence. Management practices aiming to reduce the incidence of winds, such as the use of windbreakers, could improve the management of the diseases by reducing injuries caused by winds. Moreover, our study showed that CBACs could be mixed with other fungicides and improve control of other diseases, such as BLS.

\section{REFERENCES}

AGROFIT (2021). Sistema de agrotóxicos fitossanitários. Available at: https://agrofit.agricultura.gov. br/agrofit_cons/principal_agrofit_cons. Accessed on March 10, 2021.

ALMEIDA IMG, MACIEL KW, BERIAM LOS, RODRIGUES LMR, DESTÉFANO SAL, RODRIGUES NETO J, PATRICIO FRA (2012). Increase in incidence of bacterial halo blight (Pseudomonas syringae pv. garcae), in coffee producing areas in Brazil. In: International Conference on Coffee Science 24. Proceedings. ASIC, San José, Costa Rica. p.1080-1084.
ANDREAZI E, SERA GE, SERA T, FONSECA ICB, CARDUCCI FCC, SHIGEOKA LH, SANTOS WG, PEREIRA CTM (2018). Resistance to bacterial halo blight in Arabica coffee lines derivative from the genotype C1195-5-6-2 under natural infection conditions. Crop Breeding and Applied Biotechnology 18: 110-115. (https://dx.doi. org/10.1590/1984- 70332018v18n1n17).

AVESKAMP MM, GRUYTER J, WOUDENBERG JHC, VERKLEY GJM, CROUS PW (2010). Highlights of the Didymellaceae: a polyphasic approach to characterize Phoma and related pleosporalean genera. Studies in Mycology 65: 1-60. (https:// doi.org/10.3114/sim.2010.65.01).

BAIO FHR, GABRIEL RRF, CAMOLESE HS (2015). Alteração das propriedades físico-químicas na aplicação contendo adjuvantes. Brazilian Journal of Byosistems Enginnering 9: 151-161. (https://dx. doi.org/10.18011/bioeng2015v9n2p151-161).

BOEREMA GH; GRUYTER NOORDELOOS ME; HAMERS MEC (2004). Phoma Identification manual. Differentiation of Specific and Infra-specific Taxa in Culture. Wallingford,UK. CAB International.

BULTREYS A, GHEYSEN I, ROUSSEAU G, PITCHUGINA E, PLANCHON V, MAGEIN H (2018). Antibacterial activity of fosetyl-Al, ethyl-phosphite and phosphite against Pseudomonas syringae on plant surfaces and in vitro. Plant Pathology 67: 1955-1966. (https://doi.org/10.1111/ ppa.12918).

CAZORLA FM, ARREBOLA E, OLEA F, VELASCO L, HERMOSO JM, PÉREZ-GARCÍA A, TORÉS JA, FARRÉ JM, VICENTE A (2006). Field evaluation of treatments for the control of the bacterial apical necrosis of mango (Mangifera indica) caused by Pseudomonas syringae pv. syringae. European Journal of Plant Pathology 116: 279-288. (https:// doi.org/10.1007/s10658-006-9059-7).

CELLINI A, FIORENTINI L, BURIANI G, YU J, DONATI I, CORNISH DA, NOVAK B, COSTA G, VANNESTE JL, SPINELLI F (2014). Elicitors of the salicylic acid pathway reduce incidence of bacterial canker of kiwifruit caused by Pseudomonas syringae pv. actinidae. Annals of Applied Biology 165: 441-453. (https://doi.org/10.1111/aab.12150).

CHA JS, COOKSEY DA (1991). Copper resistance in Pseudomonas syringae mediated by perisplasmic and outer membrane proteins. Proceedings of National Academy of Sciences of United 
States of America 88: 8915-8919. (https://doi. org/10.1073/pnas.88.20.8915).

COSTA AS, AMARAL JF, VIEGAS AP, SILVA DM, TEIXEIRA CG, PINHEIRO ED (1957). Bacterial halo blight of coffee in Brazil. Phytopathologische Zeitschrift 28: 427-444.

COSTA AS, SILVA DM (1960). Estudos sobre a mancha aureolada do cafeeiro. Bragantia 19: 63-68. (https://doi.org/10.1590/S000687051960000100081).

COSTA BHG, RESENDE MLV, RIBEIRO JUNIOR PM, MATHIONI SM, PADUA MA, SILVA JUNIOR MB (2014). Suppression of rust and brown eye spot diseases on coffee by phosphites and by-products of coffee and citrus industries. Journal of Phytopathology 162: 635-642. (https://doi. org/10.1111/jph.12237).

DANIEL R, GUEST D (2006). Defence responses induced by potassium phosphonate in Phytophthora palmivora-challenged Arabidopsis thaliana. Physiological and Molecular Plant Pathology 67: 194-201. (https://doi.org/10.1016/j. pmpp.2006.01.003).

FERNANDES LE, SANTOS WG, CARDUCCI FC, FONSECA ICB, RODRIGUES LMR, BERIAM LOS, PEREIRA CTM, SHIGEOKA LH, SERA GH (2020). Resistance of Arabica coffee cultivars to leaf wounds and Pseudomonas syringae under field conditions. Australian Journal of Crop Science, 14: 46-50. (https://doi: 10.21475/ajcs.20.14.01. p1781).

FIRMAN ID (1963). Elgon Die-back. Kenya Coffee 28: 9-14.

FREITAS MLO (2017). Epidemiologia e controle da mancha aureolada do cafeeiro. PhD Thesis, Universidade Federal de Lavras, Lavras, MG, Brasil. Available at: repositorio.ufla.br/jspui/bitstream/1/13253/1/TESE_Epidemiologia\%20e\%20 controle\%20da\%20mancha\%2 Oaureolada\%20 do\%20cafeeiro.pdf

GAN YT, SIDDIQUE KHM, MACLEOD WJ, JAYAKUMAR P (2006). Management options for minimizing the damage by ascochyta blight (Ascochyta rabiei) in chickpea (Cicer arietinum L.). Field Crops Research 97: 121-134. (https://doi. org/10.1016/j.fcr.2005.10.002).

HINKOSA GG, LENCHO AL, SELVARAJ T, CHAVNAN A, SADESSA K (2016). Screening, cultural and biochemical characterization of coffee bac- terial blight (Pseudomonas syringae pv. garcae van Hall) isolates from Sidama and Gedeo zones, SNNP Regional State, Ethiopia. International Journal of Life Sciences 4: 491-508.

IBGE (2016) A geografia do café/IBGE, Coordenação de Geografia. Rio de Janeiro: IBGE 136p. Available at: https://biblioteca.ibge.gov.br/visualizacao/livros/liv99002.pdf. Accessed on February 12, 2021.

ITHIRU J M, GICHURU EK, GITONGA PN, CHESEREK JJ, GICHIMU BM (2013). Methods for early evaluation for resistance to bacterial blight of coffee. African Journal of Agricultural Research 8: 2450-2454 (https://doi.org/10.5897/ AJAR2013.6717)

ITHIRU J M, GICHURU EK, ALAKONYA AE (2016). Identification of coffee genotypes with resistance to isolates of bacterial blight of coffee in Kenya. International Journal of Plant Breeding and Crop Science 3:90-98.

ITO DS, SERA T, SERA GH, DEL GROSSI L, KANAYAMA FS (2008). Resistance to bacterial blight in arabica coffee cultivars. Crop Breeding and Applied Biotechnology 8: 99-103. (https://doi. org/10.12702/1984-7033.v08n02a01).

KAIRU GM, NYANGENA CMS, CROSSE JE (1985). The effect of copper sprays on bacterial blight and coffee berry disease in Kenya. Plant Pathology 34: 207-213. (https://doi.org/10.1111/j.13653059.1985.tb01351.x).

KAIRUGM, NYANGENACMS, MUTHAMIAJE(1991). The performance of copper-based bactericides in the control of bacterial blight of coffee berry disease in Kenya. Tropical Pest Management 37: 1-5. (https://doi.org/10.1080/09670879109371526).

KEINATH AP (2012). Differential sensitivity to boscalid in conidia and ascospores of Didymella bryoniae and frequency of boscalid-insensitive isolates in South Carolina. Plant Disease 96: 228234. (https://doi.org/10.1094/PDIS-06-11-0490).

LAMICHHANE JR, OSDAGHI E, BEHLAU F, KÖHL J, JONESS JJ, AUBERTOT JN (2018). Thirteen decades of antimicrobial copper compounds applied in agriculture. A review. Agronomy for sustainable development 38: 28. (https://doi. org/10.1007/s13593-018-0503-9).

MACIEL KW, DESTEFANO SAL, BERIAM LOS, ALMEIDA IMG, PATRICIO FRA, RODRIGUES LMR, GUERREIRO FILHO O (2018). Bacterial halo 
blight of coffee crop: aggressiveness and genetic diversity of strains. Bragantia 77: 96-106. (https://dx.doi.org/10.1590/1678-4499.2016267).

MARCO G M, STALL, R E (1983). Control of bacterial spot of pepper initiated by strains of Xanthomonas campestris pv. vesicatoria that differ in sensitivity to copper. Plant Disease 67: 779-781. (https://dx.doi.org/10.1094/PD-67-779).

MATIELLO JB, ALMEIDA SR (2006). A ferrugem do cafeeiro no Brasil e o seu controle. Varginha, Brasil: Fundação Procafé.

MOHAN AK, CARDOSO RML, PAIVA MA (1978). Resistência de germoplasma de Coffea ao crestamento bacteriano incitado por Pseudomonas garcae (Amaral et al.). Pesquisa Agropecuária Brasileira 13: 53-64.

MORAES AS, SUGIMORI MH, TOMAZELLO FILHO M, CARVALHO PCT (1975). Resistência de cafeeiros a Pseudomonas garcae. Summa Phytopathologica 1: 105-110.

NGUYEN KA, FÖSTER H, ADASKAVEG JE (2018). Efficacy of copper and new bactericides for the management of olive knot in California. Plant Disease 102: 892-898. (https://apsjournals.apsnet. org/doi/10.1094/PDIS-08-17-1162-RE).

PATRICIO FRA, OLIVEIRA EG (2013). Desafios no manejo de doenças do cafeeiro. Visão Agrícola 12: 51-54. Available at: https://www.esalq.usp. br/visaoagricola/sites/default/files/va12-fitossanidade02.pdf. Accessed on March 20, 2021.

PATRICIO FRA, ALMEIDA IMG, BARROS BC, SANTOS AS, FRARE PM (2008). Effectiveness of acibenzolar-s-methyl, fungicides and antibiotics for the control of brown eye spot, bacterial blight, brown leaf spot and coffee rust in coffee. Annals of Applied Biology 152: 29-39. (https:// doi.org/10.1111/j.1744- 7348.2007.00187.x).

PETEK MR, SERA T, ALTEIA MZ (2005). Selection for frost resistance in Coffea arabica progenies carrying C. liberica var. dewevrei genes. Crop Breeding and Applied Biotechnology 5: 355-362 (https:// doi.org/10.12702/1984-7033.v05n03a14).

RAMOS AH, SHADVIA LD (1976). A dieback of coffee in Kenya. Plant Disease Reporter 60: 831-835.
RODRIGUES LMR, BRAGHINI MT, GUERREIRO FILHO O (2017). $\mathrm{SH}_{1}$ leaf rust and bacterial halo blight coffee resistances are genetically independent. Bragantia 76: 209-2012. (http://dx.doi. org/10.1590/1678-4499.171).

RODRIGUES LMR, ALMEIDA IMG, PATRICIO FRA, BERIAM LOS, MACIEL KW, BRAGHINI MT, GUERREIRO FILHO O (2013). Mancha aureolada do cafeeiro causada por Pseudomonas syringae pv. garcae. Campinas, SP, Brasil: Instituto Agronômico. (Série Tecnologia Apta. Boletim Técnico IAC, 212). Available at: https://www.iac.sp.gov. br/publicacoes/arquivos/iacbt212.pdf. Accessed on March 25, 2021.

RODRIGUES LMR, DESTÉFANO SAL, ALMEIDA IMG, BERIAM LOS, MACIEL KW, BRAGHINI MT, GUERREIRO FILHO O (2019). Multiple resistance to bacterial halo blight and bacterial leaf spot in Coffea spp. Arquivos do Instituto Biológico 86: 1-9. (https://doi.org/10.1590/18081657000632018).

SERA GH, SERA T, FAZUOLI LC (2017). IPR 102 Dwarf Arabica coffee cultivar with resistance to bacterial halo blight. Crop Breeding and Applied Biotechnology 17: 403-407. (https://dx.doi. org/10.1590/1984-70332017v17n4c60).

SUNDIN GW, CASTBLANCO LF, YUAN X, ZENG Q, YANG CH (2016). Bacterial disease management: challenges, experience, innovation and future prospects. Molecular Plant Pathology 17: 15061518. (https://doi.org/10.1111/mpp.12436).

VALLAD GE, PERNEZNY KL, WEN A, FIGUEIREDO JFL, JONES JB, MOMOL T, MUCHOVEJ RM, HAVRANEK N, ABDALLAH N, OLSON S, ROBERTS PD (2010). Comparison of kasugamycin to traditional bactericides for the management of bacterial spot on tomato. Hortscience 45: 1834-1840. (https://doi.org/10.21273/HORTSCl.45.12.1834). ZOCCOLI DM, TAKATSU AT, UESUGI CH (2011). Ocorrência de mancha aureolada em cafeeiros na Região do Triângulo Mineiro e Alto Paranaíba. Bragantia 70: 843-849. (https://doi.org/10.1590/ S0006-87052011000400017). 